\title{
Multi-model simulations of the impact of international shipping on Atmospheric Chemistry and Climate in 2000 and 2030
}

\author{
V. Eyring ${ }^{1}$, D. S. Stevenson ${ }^{2}$, A. Lauer ${ }^{1}$, F. J. Dentener ${ }^{3}$, T. Butler ${ }^{4}$, W. J. Collins ${ }^{5}$, K. Ellingsen ${ }^{6}$, M. Gauss ${ }^{6}$, \\ D. A. Hauglustaine ${ }^{7}$, I. S. A. Isaksen ${ }^{6}$, M. G. Lawrence ${ }^{4}$, A. Richter ${ }^{8}$, J. M. Rodriguez ${ }^{9}$, M. Sanderson ${ }^{5}$, \\ S. E. Strahan ${ }^{9}$, K. Sudo ${ }^{10}$, S. Szopa ${ }^{7}$, T. P. C. van Noije ${ }^{11}$, and O. Wild ${ }^{10 *}$ \\ ${ }^{1}$ DLR, Institut für Physik der Atmosphäre, Oberpfaffenhofen, Germany \\ ${ }^{2}$ University of Edinburgh, School of GeoSciences, Edinburgh, UK \\ ${ }^{3}$ European Commission, Joint Research Centre, Institute for Environment and Sustainability, Ispra, Italy \\ ${ }^{4}$ Max Planck Institute for Chemistry, Mainz, Germany \\ ${ }^{5}$ Met Office, Exeter, UK \\ ${ }^{6}$ University of Oslo, Department of Geosciences, Oslo, Norway \\ ${ }^{7}$ Laboratoire des Sciences du Climat et de l'Environnement, Gif-sur-Yvette, France \\ ${ }^{8}$ University of Bremen, Institute for Environmental Physics, Bremen, Germany \\ ${ }^{9}$ Goddard Earth Science \& Technology Center (GEST), Maryland, Washington, DC, USA \\ ${ }^{10}$ Frontier Research Center for Global Change, JAMSTEC, Yokohama, Japan \\ ${ }^{11}$ Royal Netherlands Meteorological Institute (KNMI), Atmospheric Composition Research, De Bilt, the Netherlands \\ * now at: University of Cambridge, Centre for Atmospheric Science, Cambridge, UK
}

Received: 1 August 2006 - Published in Atmos. Chem. Phys. Discuss.: 12 September 2006

Revised: 25 January 2007 - Accepted: 1 February 2007 - Published: 14 February 2007

\begin{abstract}
The global impact of shipping on atmospheric chemistry and radiative forcing, as well as the associated uncertainties, have been quantified using an ensemble of ten state-of-the-art atmospheric chemistry models and a predefined set of emission data. The analysis is performed for present-day conditions (year 2000) and for two future ship emission scenarios. In one scenario ship emissions stabilize at 2000 levels; in the other ship emissions increase with a constant annual growth rate of $2.2 \%$ up to 2030 (termed the "Constant Growth Scenario" (CGS)). Most other anthropogenic emissions follow the IPCC (Intergovernmental Panel on Climate Change) SRES (Special Report on Emission Scenarios) A2 scenario, while biomass burning and natural emissions remain at year 2000 levels. An intercomparison of the model results with observations over the Northern Hemisphere $\left(25^{\circ}-60^{\circ} \mathrm{N}\right)$ oceanic regions in the lower troposphere showed that the models are capable to reproduce ozone $\left(\mathrm{O}_{3}\right)$ and nitrogen oxides $\left(\mathrm{NO}_{\mathrm{x}}=\mathrm{NO}+\mathrm{NO}_{2}\right)$ reasonably well, whereas sulphur dioxide $\left(\mathrm{SO}_{2}\right)$ in the marine boundary layer is significantly underestimated. The most pronounced changes in annual mean tropospheric $\mathrm{NO}_{2}$ and sulphate columns are simulated over the Baltic and North Seas. Other significant changes occur over the North Atlantic, the Gulf of Mexico and along the main shipping lane from Europe to Asia, across the Red and Arabian Seas. Maximum
\end{abstract}

Correspondence to: V. Eyring

(Veronika.Eyring@dlr.de) contributions from shipping to annual mean near-surface $\mathrm{O}_{3}$ are found over the North Atlantic (5-6 ppbv in 2000; up to $8 \mathrm{ppbv}$ in 2030). Ship contributions to tropospheric $\mathrm{O}_{3}$ columns over the North Atlantic and Indian Oceans reach 1 DU in 2000 and up to $1.8 \mathrm{DU}$ in 2030. Tropospheric $\mathrm{O}_{3}$ forcings due to shipping are $9.8 \pm 2.0 \mathrm{~mW} / \mathrm{m}^{2}$ in 2000 and $13.6 \pm 2.3 \mathrm{~mW} / \mathrm{m}^{2}$ in 2030 . Whilst increasing $\mathrm{O}_{3}$, ship $\mathrm{NO}_{\mathrm{x}}$ simultaneously enhances hydroxyl radicals over the remote ocean, reducing the global methane lifetime by $0.13 \mathrm{yr}$ in 2000 , and by up to $0.17 \mathrm{yr}$ in 2030 , introducing a negative radiative forcing. The models show future increases in $\mathrm{NO}_{\mathrm{x}}$ and $\mathrm{O}_{3}$ burden which scale almost linearly with increases in $\mathrm{NO}_{\mathrm{x}}$ emission totals. Increasing emissions from shipping would significantly counteract the benefits derived from reducing $\mathrm{SO}_{2}$ emissions from all other anthropogenic sources under the A2 scenario over the continents, for example in Europe. Globally, shipping contributes 3\% to increases in $\mathrm{O}_{3}$ burden between 2000 and 2030, and $4.5 \%$ to increases in sulphate under A2/CGS. However, if future ground based emissions follow a more stringent scenario, the relative importance of ship emissions will increase. Inter-model differences in the simulated $\mathrm{O}_{3}$ contributions from ships are significantly smaller than estimated uncertainties stemming from the ship emission inventory, mainly the ship emission totals, the distribution of the emissions over the globe, and the neglect of ship plume dispersion.

Published by Copernicus GmbH on behalf of the European Geosciences Union. 


\section{Introduction}

Seagoing ships emit exhaust gases and particles into the marine boundary layer contributing significantly to the total budget of anthropogenic emissions from the transportation sector (e.g. Olivier et al., 2001; Eyring et al., 2005a). Emissions of nitrogen oxides $\left(\mathrm{NO}_{\mathrm{x}}=\mathrm{NO}+\mathrm{NO}_{2}\right)$ from shipping lead to tropospheric ozone $\left(\mathrm{O}_{3}\right)$ formation and perturb the hydroxyl radical $(\mathrm{OH})$ field, and hence the lifetime of methane $\left(\mathrm{CH}_{4}\right)$. These changes affect the Earth's radiation budget as $\mathrm{O}_{3}$ and $\mathrm{CH}_{4}$ are greenhouse gases. Evidence for the importance of ship emissions comes from satellite observations from GOME (Beirle et al., 2004) and SCIAMACHY (Richter et al., 2004) that show enhanced tropospheric $\mathrm{NO}_{2}$ columns along the major international shipping routes in the Red Sea and over the Indian Ocean. A number of atmospheric model studies quantifying the impact of ship emissions on the chemical composition of the atmosphere and on climate have been published in recent years. All these studies used a global fuel consumption of about 160 million metric tons (Mt, or $\mathrm{Tg}$ ) per year derived from energy statistics (Corbett and Fischbeck, 1997; Corbett et al., 1999; Olivier et al., 2001; Endresen et al., 2003). However, there is an ongoing discussion on the present-day value, as recent estimates of the fuel consumption calculated with an activity-based approach indicate higher fuel consumption of around $280 \mathrm{Mt}$ (Corbett and Köhler, 2003; Eyring et al., 2005a), suggesting that previous model studies may have significantly underestimated emissions. Despite this, these models tend to overestimate oceanic $\mathrm{NO}_{\mathrm{x}}$ over parts of the North Atlantic and the Pacific (Lawrence and Crutzen, 1999; Kasibahtla et al., 2000; Davis et al., 2001; Endresen et al., 2003). One possibility to reduce this discrepancy might be to account for ship plume dispersion in global models (Kasibhatla et al., 2000; Davis et al., 2001; Song et al., 2003; von Glasow et al., 2003; Chen et al., 2005). In ship plumes the lifetime of $\mathrm{NO}_{\mathrm{x}}$ is significantly reduced compared to the background and $\mathrm{NO}_{x}$ in the plume is rapidly oxidised. Some $\mathrm{NO}_{\mathrm{x}}$ is therefore lost at scales smaller than the typical grid size of global models $(100-500 \mathrm{~km})$. These sub-grid-scale processes have to be parameterised in global models, e.g., by the use of effective emission indices depending on the meteorology and background conditions. However, there is no clear consensus on the effective global emissions from ships. In this study we use relatively low global emission estimates and neglect ship plume chemistry.

In addition to $\mathrm{NO}_{\mathrm{x}}$, shipping contributes significantly to global sulphur dioxide $\left(\mathrm{SO}_{2}\right)$ emissions as the average sulphur content of the fuel burned in marine diesel engines of $2.4 \%$ is high compared to other transport sectors (EPA, 2002). In large areas of the Northern Hemisphere $\mathrm{SO}_{2}$ emissions from ships are comparable to biogenic dimethyl sulphide (DMS) emissions, which are the main natural source of sulphur over the oceans (Corbett et al., 1999; Capaldo et al., 1999; Derwent et al., 2005). The main oxidation pro- cesses for $\mathrm{SO}_{2}$ are believed to be either via $\mathrm{OH}$ in the gas phase or in the liquid phase via $\mathrm{O}_{3}$ or $\mathrm{H}_{2} \mathrm{O}_{2}$ in cloud droplets (Langner and Rohde, 1991). As $\mathrm{SO}_{2}$ is primarily controlled by aqueous processes, it is expected that $\mathrm{SO}_{2}$ is largely independent of enhanced $\mathrm{OH}$ in the plume (Davis et al., 2001). In addition to sulphate particles resulting from $\mathrm{SO}_{2}$ emissions, ships also release black carbon (BC) and particulate organic matter (POM). The increase in sulphate, BC and POM concentrations has a direct and indirect effect on climate. The direct effect results from enhanced scattering of solar radiation (Haywood and Shine, 1995). The indirect effect of particles from shipping results from changes in the microphysical, optical and radiative properties of low marine clouds (Scorer, 1987; Capaldo et al., 1999, Durkee et al., 2000; Schreier et al., 2006).

The numbers of ships in the world merchant fleet has increased by $35 \%$ over the past 50 years, accompanied by a significant increase in emission totals (Eyring et al., 2005a). At the end of the year 2001 it consisted of around 90000 oceangoing ships of 100 gross tons (GT) and above (Lloyd's, 2002). Shipping is currently one of the less regulated sources of anthropogenic emissions with a high reduction potential through technological improvements, alternative fuels and ship modifications. Emission scenario calculations up to the year 2050 show that if no control measures are taken beyond existing International Maritime Organization (IMO) regulations (IMO, 1998), $\mathrm{NO}_{\mathrm{x}}$ emissions might increase with an annual growth rate of $1.7 \%$ between 2000 and 2030 and up to a value of present day global road transport by $2050(38.8 \mathrm{Tg}$ $\left(\mathrm{NO}_{2}\right) / \mathrm{yr}$ ) (Eyring et al., 2005b). If the sulphur content remains at present day levels a doubling of ship $\mathrm{SO}_{2}$ emissions can be expected. However, given the air quality issue of shipping emissions, further emission reductions of total $\mathrm{NO}_{\mathrm{x}}$ and $\mathrm{SO}_{2}$ emissions are likely. Using aggressive $\mathrm{NO}_{\mathrm{x}}$ emission reduction technologies, a significant decrease up to $85 \%$ of today's $\mathrm{NO}_{\mathrm{x}}$ emissions could be reached through technological improvements by 2050, in spite of a growing fleet. A summary of current national and international maritime regulations is given in Eyring et al. (2005b).

Currently there is a large uncertainty about the overall impact of emissions from international shipping which can be explored using global atmospheric models. The first key question addressed in this study is how $\mathrm{NO}_{\mathrm{x}}$ and $\mathrm{SO}_{2}$ emissions from international shipping might influence atmospheric chemistry, in particular tropospheric $\mathrm{O}_{3}$ and sulphate, in the next three decades, if these emissions increase unabated. To address this, impacts of $\mathrm{NO}_{\mathrm{x}}$ and $\mathrm{SO}_{2}$ emissions from international shipping are assessed with the help of an ensemble of state-of-the-art global atmospheric chemistry models. The second major issue is to examine the range of results given by the individual models compared to the ensemble mean to estimate the uncertainties introduced by different modelling approaches. The participating models have also been evaluated and used in accompanying studies (e.g. Stevenson et al., 2006; Dentener et al., 
Table 1. Participating models. The models are listed alphabetically by name. The horizontal resolution is given in degrees latitude $\times$ longitude.

\begin{tabular}{|c|c|c|c|c|c|c|c|}
\hline Model & Institute & Contact author & $\begin{array}{l}\text { Resolution } \\
\text { (lon/lat) } \\
\text { levels, top } \\
\text { level }\end{array}$ & $\begin{array}{l}\text { Underlying me- } \\
\text { teorology }\end{array}$ & $\begin{array}{l}\text { Tropospheric } \\
\text { chemistry }\end{array}$ & $\begin{array}{l}\text { Stratospheric } \\
\text { chemistry }\end{array}$ & References \\
\hline $\begin{array}{l}\text { CHASER- } \\
\text { CTM }\end{array}$ & $\begin{array}{l}\text { FRCGC/ } \\
\text { JAMSTEC }\end{array}$ & K. Sudo & $\begin{array}{l}2.8^{\circ} \times 2.8^{\circ} \\
\mathrm{L} 32 \\
3 \mathrm{hPa}\end{array}$ & $\begin{array}{l}\text { CTM: ECMWF } \\
\text { operational anal- } \\
\text { ysis data for } 2000\end{array}$ & $\begin{array}{l}53 \text { species } \\
140 \text { reactions, } \\
\text { Interactive } \mathrm{SO}_{4} \\
\text { aerosol }\end{array}$ & $\begin{array}{l}\mathrm{O}_{3} \text { relaxed above } \\
50 \mathrm{hPa} \text { to observa- } \\
\text { tions }\end{array}$ & $\begin{array}{l}\text { Sudo et al. (2002a,b) } \\
\text { Sudo et al. (2003) }\end{array}$ \\
\hline $\begin{array}{l}\text { GMI/ } \\
\text { CCM3 }\end{array}$ & $\begin{array}{l}\text { NASA Global } \\
\text { Modeling } \\
\text { Iniative }\end{array}$ & $\begin{array}{l}\text { J. M. Ro- } \\
\text { driguez } \\
\text { S. Strahan }\end{array}$ & $\begin{array}{l}5^{\circ} \times 4^{\circ} \\
\mathrm{L} 52 \\
0.006 \mathrm{hPa}\end{array}$ & $\begin{array}{l}\text { CTM: NCAR } \\
\text { MACCM3 }\end{array}$ & $\begin{array}{l}85 \text { species } \\
\text { offline aerosol } \\
\text { surface area }\end{array}$ & $\begin{array}{l}\mathrm{O}_{3} \text { influx from } \\
\text { SYNOZ: } 550 \mathrm{Tg} / \mathrm{yr}\end{array}$ & $\begin{array}{l}\text { Rotman et al. (2001) } \\
\text { Bey et al. (2001) }\end{array}$ \\
\hline $\begin{array}{l}\text { GMI/ } \\
\text { DAO }\end{array}$ & $\begin{array}{l}\text { NASA Global } \\
\text { Modeling } \\
\text { Initiative }\end{array}$ & $\begin{array}{l}\text { J. M. Ro- } \\
\text { driguez } \\
\text { S. Strahan }\end{array}$ & $\begin{array}{l}5^{\circ} \times 4^{\circ} \\
\mathrm{L} 46 \\
0.048 \mathrm{hPa}\end{array}$ & $\begin{array}{l}\text { CTM: GEOS-1- } \\
\text { DAS assimilated } \\
\text { fields for March } \\
\text { 1997-Feb } 1998\end{array}$ & $\begin{array}{l}85 \text { species } \\
\text { offline aerosol } \\
\text { surface area }\end{array}$ & $\begin{array}{l}\mathrm{O}_{3} \text { influx from } \\
\text { SYNOZ: } 550 \mathrm{Tg} / \mathrm{yr}\end{array}$ & $\begin{array}{l}\text { Rotman et al. (2001) } \\
\text { Bey et al. (2001) }\end{array}$ \\
\hline LMDz/ INCA & LSCE & $\begin{array}{l}\text { D. Hauglus- } \\
\text { taine } \\
\text { S. Szopa }\end{array}$ & $\begin{array}{l}3.75^{\circ} \times 2.5^{\circ} \\
\mathrm{L} 19 \\
3 \mathrm{hPa}\end{array}$ & $\begin{array}{l}\text { GCM: nudged to } \\
\text { ECMWF ERA- } \\
40 \text { reanalysis } \\
\text { data for } 2000\end{array}$ & $\begin{array}{l}85 \text { species } \\
303 \text { reactions }\end{array}$ & $\begin{array}{l}\text { Stratospheric } \mathrm{O}_{3} \\
\text { nudged towards } \\
\text { climatologies } \\
\text { above } 380 \mathrm{~K}\end{array}$ & $\begin{array}{l}\text { Sadourny and Laval } \\
(1984) \\
\text { Hauglustaine } \\
\text { al. (2004) }\end{array}$ \\
\hline $\begin{array}{l}\text { MATCH- } \\
\text { MPIC }\end{array}$ & $\begin{array}{lr}\text { Max Planck } \\
\text { Institute for } \\
\text { Chemistry } \\
\text { NCAR }\end{array}$ & $\begin{array}{l}\text { T. Butler } \\
\text { M. Lawrence }\end{array}$ & $\begin{array}{l}5.6^{\circ} \times 5.6^{\circ} \\
\mathrm{L} 28 \\
2 \mathrm{hPa}\end{array}$ & $\begin{array}{l}\text { CTM: } \\
\text { NCEP/NCAR } \\
\text { reanalysis data } \\
\text { for } 2000\end{array}$ & $\begin{array}{l}60 \text { species } \\
145 \text { reactions }\end{array}$ & $\begin{array}{l}\text { Zonal mean } \mathrm{O}_{3} \\
\text { climatology above } \\
30 \mathrm{hPa} \text {; } \\
\text { above tropopause: } \\
\mathrm{NO}_{\mathrm{y}} \text { set to pre- } \\
\text { scribed } \mathrm{NO}_{\mathrm{y}} / \mathrm{O}_{3} \\
\text { ratios }\end{array}$ & $\begin{array}{l}\text { von Kuhlmann et al. } \\
(2003 a, b) \\
\text { Lawrence et al. } \\
\text { (1999) } \\
\text { Rasch et al. (1997) }\end{array}$ \\
\hline $\begin{array}{l}\text { STOCHEM- } \\
\text { HadAM3 }\end{array}$ & $\begin{array}{l}\text { University of } \\
\text { Edinburgh }\end{array}$ & D. Stevenson & $\begin{array}{l}5^{\circ} \times 5^{\circ} \\
\mathrm{L} 9 \\
100 \mathrm{hPa}\end{array}$ & $\begin{array}{l}\text { GCM: } \\
\text { HadAM3 vn4.5 }\end{array}$ & $\begin{array}{l}70 \text { species } \\
174 \text { reactions } \\
\mathrm{SO}_{\mathrm{x}}-\mathrm{NO}_{\mathrm{y}}-\mathrm{NH}_{\mathrm{x}} \\
\text { aerosols; interac- } \\
\text { tive }\end{array}$ & $\begin{array}{l}\text { Prescribed } \mathrm{O}_{3} \text { con- } \\
\text { centration gradient } \\
\text { at } 100 \mathrm{hPa}\end{array}$ & $\begin{array}{l}\text { Collins et al. (1997) } \\
\text { Stevenson } \\
\text { al. (2004) }\end{array}$ \\
\hline TM4 & KNMI & T. van Noije & $\begin{array}{l}3^{\circ} \times 2^{\circ} \\
\mathrm{L} 25 \\
0.48 \mathrm{hPa}\end{array}$ & $\begin{array}{l}\text { CTM: } \\
\text { ECMWF 3-6- } \\
\text { h operational } \\
\text { forecasts for } \\
2000\end{array}$ & $\begin{array}{l}37 \text { species }(22 \\
\text { transported) } \\
95 \text { reactions } \\
\mathrm{SO}_{\mathrm{x}}-\mathrm{NO}_{\mathrm{y}}-\mathrm{NH}_{\mathrm{x}} \\
\text { aerosols, interac- } \\
\text { tive }\end{array}$ & $\begin{array}{l}\mathrm{O}_{3} \text { nudged towards } \\
\text { climatology above } \\
123 \mathrm{hPa} \text { : except } \\
30 \mathrm{~N}-30 \mathrm{~S}, \text { above } \\
60 \mathrm{hPa}\end{array}$ & $\begin{array}{l}\begin{array}{l}\text { Dentener et al. } \\
(2003)\end{array} \\
\text { van Noije et al. } \\
(2004)\end{array}$ \\
\hline UIO.CTM2 & $\begin{array}{l}\text { University of } \\
\text { Oslo }\end{array}$ & $\begin{array}{l}\text { K. Ellingsen } \\
\text { M. Gauss }\end{array}$ & $\begin{array}{l}2.8^{\circ} \times 2.8^{\circ} \\
\mathrm{L} 40 \\
10 \mathrm{hPa}\end{array}$ & $\begin{array}{l}\text { CTM: } \\
\text { ECMWF-IFS } \\
\text { forecast data }\end{array}$ & 58 species & $\begin{array}{lr}\mathrm{O}_{3}, & \mathrm{HNO}_{3} \\
\text { and } \mathrm{NO}_{\mathrm{X}} & \text { from } \\
\text { OsloCTM2 } & \text { model } \\
\text { run with strato- } \\
\text { spheric chemistry }\end{array}$ & $\begin{array}{l}\text { Sundet (1997) } \\
\text { Isaksen et al. (2005) }\end{array}$ \\
\hline
\end{tabular}

2006a,b; Shindell et al., 2006, van Noije et al., 2006) as part of the European Union project ACCENT (Atmospheric Composition Change: the European NeTwork of excellence; http://www.accent-network.org).

The models and model simulations, together with the method to analyse the results are described in Sect. 2. The models' ability to simulate $\mathrm{O}_{3}, \mathrm{NO}_{\mathrm{x}}$ and $\mathrm{SO}_{2}$ over the remote ocean is evaluated in Sect. 3.1. Large-scale chemistry effects on $\mathrm{NO}_{2}$ and $\mathrm{O}_{3}$ distributions due to $\mathrm{NO}_{\mathrm{x}}$ emissions from ships are discussed in Sect. 3.2 for present-day condi- tions and in Sect. 3.3 for 2030, while impacts of $\mathrm{SO}_{2}$ emissions from ships on sulphate distributions are discussed in Sect. 3.4. In Sect. 3.5 radiative forcings (RFs) from tropospheric $\mathrm{O}_{3}$ calculated with the help of an offline radiation scheme are summarised and RFs due to carbon dioxide $\left(\mathrm{CO}_{2}\right), \mathrm{CH}_{4}$, and sulphate are roughly estimated. Section 4 discusses the impact of volatile organic compounds (VOC) and carbon monoxide (CO) emissions from ships and possible uncertainties in the presented results mainly stemming from the emission inventory itself, the neglect of plume 
Table 2. Specified global annual anthropogenic (not including biomass burning emissions) surface emission totals for each scenario.

\begin{tabular}{|c|c|c|c|c|c|c|}
\hline \multirow[t]{2}{*}{ Name } & \multirow[t]{2}{*}{ Meteorology } & & \multicolumn{2}{|c|}{$\begin{array}{l}\text { Emissions } \\
\mathrm{NO}_{\mathrm{x}}(\operatorname{Tg} \mathrm{N})\end{array}$} & \multicolumn{2}{|c|}{$\mathrm{SO}_{\mathrm{x}}(\mathrm{Tg} \mathrm{S})$} \\
\hline & & & Total & From Shipping & Total & From Shipping \\
\hline S1 & 2000 & 2000 (EDGAR3.2) & 27.80 & 3.10 & 54.00 & 3.88 \\
\hline S1w & 2000 & $\begin{array}{l}2000 \text { (EDGAR3.2), but without ship emis- } \\
\text { sions }\end{array}$ & 24.70 & 0.00 & 50.12 & 0.00 \\
\hline S4 & 2000 & $\begin{array}{l}2030 \text { SRES A2, but with ship emissions of the } \\
\text { year } 2000\end{array}$ & 54.60 & 3.10 & 100.00 & 3.88 \\
\hline $\mathrm{S} 4 \mathrm{~s}$ & 2000 & $\begin{array}{l}2030 \text { SRES A2, Traffic A2s; Ship emissions } \\
\text { increase with a flat increase of } 2.2 \% \text { /yr com- } \\
\text { pared to the year } 2000\end{array}$ & 57.45 & 5.95 & 103.48 & 7.36 \\
\hline S4w & 2000 & 2030 SRES A2, but without ship emissions & 51.50 & 0.00 & 96.12 & 0.00 \\
\hline
\end{tabular}

chemistry and assumptions in the future scenarios for background as well as ship emissions. Section 5 closes with a summary and conclusions.

\section{Models and model simulations}

\subsection{Participating Models}

Ten global atmospheric chemistry models have participated in this model inter-comparison. Seven of the ten models are Chemistry-Transport Models (CTMs) driven by meteorological assimilation fields and three models are atmospheric General Circulation Models (GCMs). Two of the GCMs are driven with the dynamical fields calculated by the GCM in climatological mode, but the fully coupled mode (interaction between changes in radiatively active gases and radiation) has been switched off in the simulations of this study. The other GCM runs in nudged mode, where winds and temperature fields are assimilated towards meteorological analyses. Therefore, changes in the chemical fields do not influence the radiation and hence the meteorology in any of the model simulations used here, and for a given model each scenario is driven by identical meteorology. The main characteristics of the ten models are summarised in Table 1 and the models are described in detail in the cited literature.

The horizontal resolution ranges from $5.6^{\circ} \times 5.6^{\circ}$ (MATCH-MPIC) to $2.8^{\circ} \times 2.8^{\circ} \quad$ (CHASER-CTM, FRSGC/UCI, UIO.CTM2) and $3^{\circ} \times 2^{\circ}$ (TM4). The vertical resolution varies in terms of number of vertical layers and upper boundary and ranges from 9 layers with a model top at $100 \mathrm{hPa}$ (STOCHEM-HadAM3) to 52 layers with a model top at $0.006 \mathrm{hPa}(\mathrm{GMI} / \mathrm{CCM} 3)$.

All models use detailed tropospheric chemistry schemes even though notable differences exist between the models, e.g. in the hydrocarbon chemistry. Of the ten models, four included the tropospheric sulphur cycle (CHASER-CTM, STOCHEM-HadAM3, STOCHEM-HadGEM, and TM4). These models include anthropogenic and natural sulphur sources, and account for oxidation in the gas phase by $\mathrm{OH}$, and in the aqueous phase (in cloud droplets) by $\mathrm{H}_{2} \mathrm{O}_{2}$ and $\mathrm{O}_{3}$. Sulphate aerosol is predominantly removed by wetdeposition processes. Models also differ in the parameterisation of sub-grid scale convection, the representation of cloud and hydrological processes, dry and wet deposition, and boundary layer mixing and a variety of different advection schemes are used.

Differences in the main characteristics as listed above will lead to differences in the modelled response to $\mathrm{NO}_{\mathrm{x}}$ and $\mathrm{SO}_{2}$ emissions from shipping, even if near-identical forcings (e.g., sea surface temperatures, natural and anthropogenic emissions, and meteorology) are used. A more detailed discussion of the sources of differences between the models is included in Stevenson et al. (2006).

\subsection{Model Simulations}

Two of the five simulations that have been defined as part of the wider PHOTOCOMP-ACCENT-IPCC study have been used in this work: a year 2000 base case (S1) and a year 2030 emissions case (S4) following the IPCC (Intergovernmental Panel on Climate Change) SRES (Special Report on Emission Scenarios) A2 scenario (IPCC, 2000). Full details on the emissions used in the S1 and S4 simulations are summarised in Stevenson et al. (2006) and only the key aspects for this study are given here. All models used the same anthropogenic and biomass burning emissions, but variable natural emissions. For example, for $\mathrm{NO}_{\mathrm{x}}$, natural sources from soils and lightning differ between the models, but this has little impact over the oceans. For $\mathrm{SO}_{2}$, natural sources from volcanoes and oceanic DMS differ. The latter has some impact on absolute values of $\mathrm{SO}_{2}$ over the oceans, but little impact on changes due to ships. The differences in natural emissions are not thought to be a major source of inter-model differences in the results presented here. To retain consistency with all other emissions, ship emissions in the year 2000 (S1) are based on the EDGAR3.2 dataset (Olivier et al., 2001) at a spatial resolution of $1^{\circ}$ latitude $\times 1^{\circ}$ longitude. The global distribution of ship emissions in EDGAR3.2 is based on the world's main shipping routes and traffic intensities (Times 


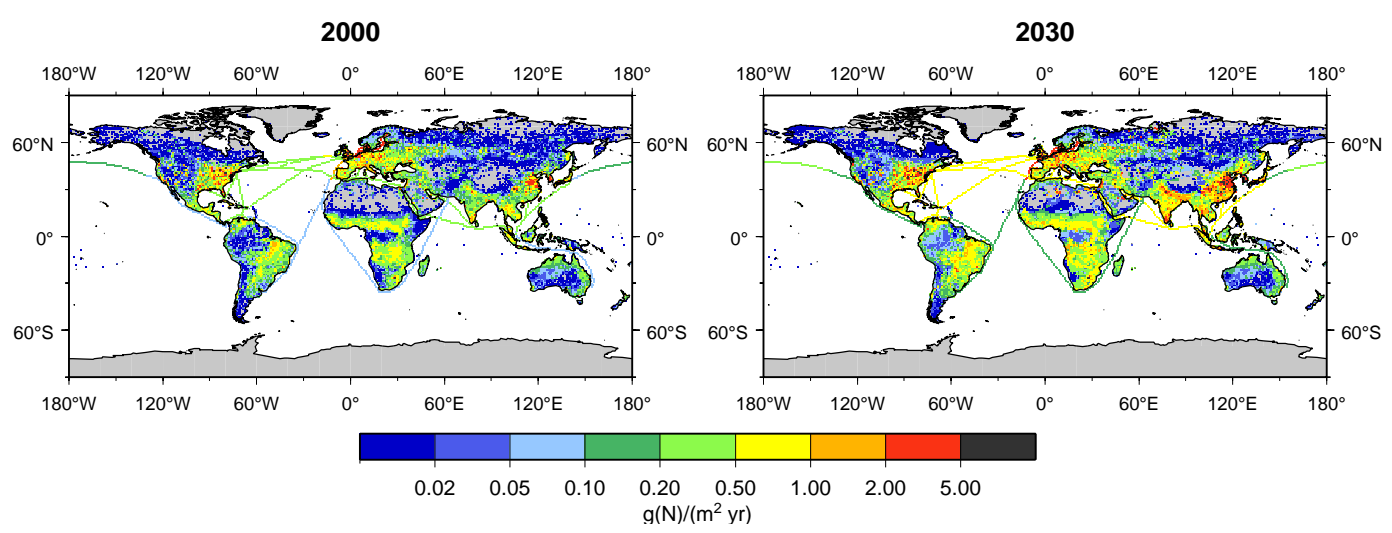

Fig. 1. Annual surface $\mathrm{NO}_{\mathrm{x}}$ emissions including industry and power generation, traffic, domestic heating, and biomass burning (average 1997-2002 (van der Werf, 2004) in $\mathrm{g}(\mathrm{N}) /\left(\mathrm{m}^{2} \mathrm{yr}\right.$ ). The left plot shows the emissions used as input for the model experiment $\mathrm{S} 1$ (year 2000 , $38.0 \mathrm{Tg}(\mathrm{N}) / \mathrm{yr}$ total), the right plot the emissions for experiment $\mathrm{S} 4 \mathrm{~s}$ (year 2030, 67.6 $\mathrm{Tg}(\mathrm{N}) / \mathrm{yr}$ total).

Books, 1992; IMO, 1992). EDGAR3.2 includes data for 1995, which have been scaled to 2000 values assuming a growth rate of $1.5 \% / y r$, resulting in annual $\mathrm{NO}_{\mathrm{x}}$ and $\mathrm{SO}_{2}$ emissions of 3.10 $\mathrm{Tg}(\mathrm{N})$ and $3.88 \mathrm{Tg}(\mathrm{S})$, respectively, similar to the emission totals published by Corbett et al. (1999). Table 2 summarises the global annual anthropogenic surface emission and ship emission totals for $\mathrm{NO}_{\mathrm{x}}$ and $\mathrm{SO}_{2}$. In the 2000 simulation (S1), ship emissions account for about $11.2 \%$ of all anthropogenic surface nitrogen oxide emissions and for about $7.2 \%$ of all anthropogenic sulphur emissions. Other emissions from ships such as $\mathrm{CO}$, particulate matter, $\mathrm{CH}_{4}$ and VOC were not included in this inventory and were therefore not considered in the reference simulations. The effect of CO and VOC emissions from ships is quantified with the help of sensitivity simulations carried out with a single model (MATCH-MPIC) in Sect. 4.1.2.

As noted in Stevenson et al. (2006) in the S4 simulation emissions from ships were included at year 2000 levels by mistake. All other anthropogenic sources (except biomass burning emissions, which remain fixed at year 2000 levels) vary according to A2 broadly representing a pessimistic future situation. The simulation S4 is used here to assess the impact of ship emissions under different background levels. An additional model simulation for 2030 (S4s) has been designed to assess the impact of shipping if emission growth remains unabated. Ship emissions in S4s are based on a "Constant Growth Scenario" (CGS) in which emission factors are unchanged and emissions increase with an annual growth rate of $2.2 \%$ between 2000 and 2030. In the S4s scenario emissions from shipping increase to $5.95 \mathrm{Tg}(\mathrm{N})$ for $\mathrm{NO}_{\mathrm{x}}$ and 7.36 $\mathrm{Tg}(\mathrm{S})$ for $\mathrm{SO}_{2}$ in 2030. As an example, the global distributions of surface $\mathrm{NO}_{\mathrm{x}}$ emissions for the years 2000 (S1) and 2030 (S4s) are displayed in Fig. 1. Vessel traffic distributions are assumed to stay the same for all model simulations presented here.

To assess the impact of ship emissions on chemistry and climate in 2000 and 2030, two sensitivity simulations have been defined that use identical conditions to $\mathrm{S} 1$ or $\mathrm{S} 4 / \mathrm{S} 4 \mathrm{~s}$ except that ship emissions are excluded. The year 2000 and 2030 experiments without ship emissions are denoted as S1w and $\mathrm{S} 4 \mathrm{w}$.

All 2030 model experiments (S4, S4s and S4w) are driven by the same meteorological data as the 2000 simulations (S1 and $\mathrm{S} 1 \mathrm{w}$ ). Global methane mixing ratios have been specified across the model domain (1760 ppbv in 2000 and 2163 ppbv in 2030) to save time spinning up the models and to help constrain the results (for details see Stevenson et al., 2006). Nine of the ten models performed single year simulations with spin-ups of at least 3 months and one model (STOCHEMHadGEM) performed a four year simulation. For the multiannual simulations the results have been averaged over all four years to reduce the effects of inter-annual variability.

\subsection{Model Analyses}

Each model provided output for 3-D monthly mean $\mathrm{NO}_{\mathrm{x}}$, $\mathrm{O}_{3}$ and sulphate mixing ratios as well as the mass of each grid-box on the native model grid for all five simulations. As models used a variety of vertical co-ordinate systems and resolutions, the output has been converted to the same common vertical grid as used in Stevenson et al. (2006). Model results are interpolated to the 19 hybrid (sigma-pressure) levels of the Met Office HadAM3 model where up to 14 of these levels span the troposphere. Results were also interpolated to a common horizontal resolution of $5^{\circ} \times 5^{\circ}$. To calculate the ensemble mean on the common grid the simulated fields have been masked at the chemical tropopause $\left(\mathrm{O}_{3}=150 \mathrm{ppbv}\right)$ similar to the method applied in Stevenson et al. (2006). For the 2000 simulations (S1 and S1w) we apply a consistent mask by using the $\mathrm{O}_{3}$ field from the $\mathrm{S} 1 \mathrm{w}$ simulation for each model and all species. For the $2030 \mathrm{sim}$ ulations ( $\mathrm{S} 4, \mathrm{~S} 4 \mathrm{~s}$, and $\mathrm{S} 4 \mathrm{w}$ ) the $\mathrm{S} 4 \mathrm{w} \mathrm{O} \mathrm{O}_{3}$ field is used to mask the tropopause. To calculate global tropospheric burdens, 

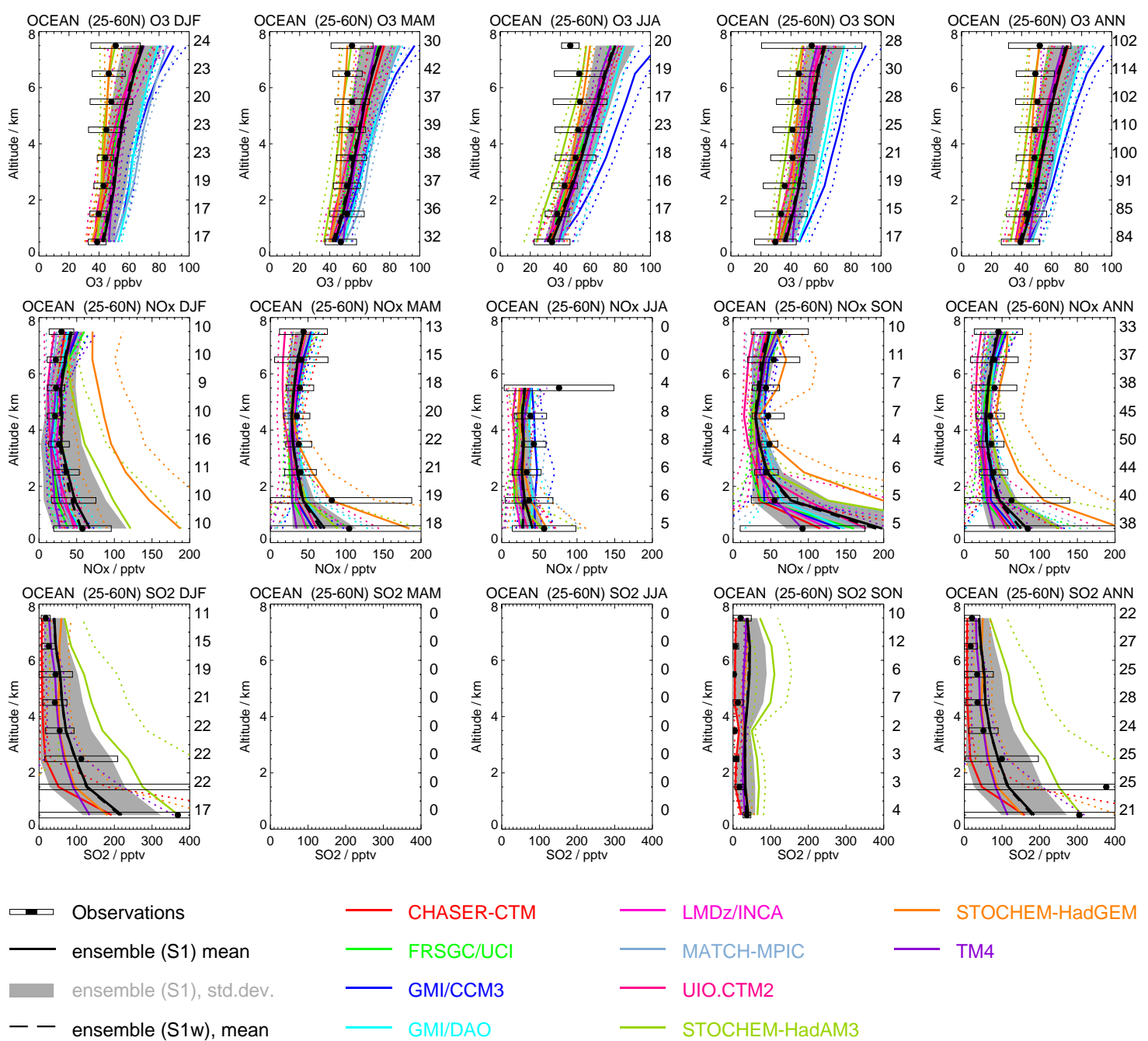

- STOCHEM-HadGEM TM4

Fig. 2. Seasonal and annual means of $\mathrm{O}_{3}$ (upper row, ppbv), $\mathrm{NO}_{\mathrm{x}}$ (middle row, pptv) and $\mathrm{SO}_{2}$ (lower row, pptv) for the Northern Hemisphere $\left(25^{\circ}-60^{\circ} \mathrm{N}\right)$ oceanic regions obtained from a compilation of observations (Emmons et al., 2000 plus updates) and calculated by the models (S1 simulation). The mean values of the individual models are shown with solid coloured lines and the standard deviation with dotted coloured lines. The ensemble mean (all models) is drawn as dashed black line for the S1w simulation and as solid black line for the S1 simulation, the intermodel standard deviation for S1 as grey shaded areas, and the observations as filled black circles (mean) and white rectangles (standard deviation).

model results were masked in the same way $\left(\mathrm{O}_{3}=150 \mathrm{ppbv}\right)$ but summed on their native grids, to avoid the introduction of errors associated with the interpolation (Sect. 3.3.2). The impact of ship emissions on $\mathrm{NO}_{\mathrm{x}}, \mathrm{O}_{3}$ and sulphate distributions is assessed by calculating the difference between the reference simulation (S1 for 2000; S4 or S4s for 2030) and the ensemble mean of the no-ships scenario (S1w for 2000; $\mathrm{S} 4 \mathrm{w}$ for 2030). For the calculation of instantaneous tropospheric $\mathrm{O}_{3}$ forcings the differences in $\mathrm{O}_{3}$ fields between sensitivity and reference simulations on the common grid were used (Sect. 3.5).

\section{Results}

\subsection{Comparison of model results with observations}

The models have been evaluated in accompanying studies. For example, $\mathrm{O}_{3}$ fields have been compared to ozonesonde measurements (Stevenson et al., 2006), $\mathrm{NO}_{2}$ columns have been compared to three state-of-the-art retrievals from measurements of the Global Ozone Monitoring Experiment (GOME) (van Noije et al., 2006), CO has been compared to near-global observations from the MOPITT instrument and local surface measurements (Shindell et al., 2006), deposition budgets have been compared to nearly all information on wet and dry deposition available worldwide (Dentener 

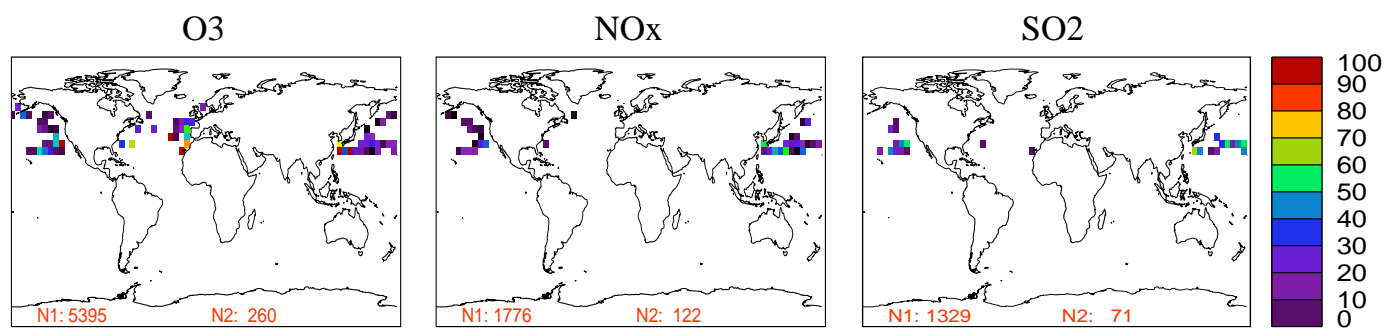

Fig. 3. Geographical distribution of the number of observations in the Emmons et al. (2000) plus updates data set for $\mathrm{O}_{3}, \mathrm{NO}_{\mathrm{x}}$, and $\mathrm{SO}_{2}$ in the Northern Hemisphere $\left(25^{\circ}-60^{\circ} \mathrm{N}\right)$ oceanic regions in the altitude range $0-3 \mathrm{~km}$. N1 gives the total number of individual observations and $\mathrm{N} 2$ the total number of $5^{\circ} \times 5^{\circ}$ grid boxes that include at least one observation.

et al., 2006b), and finally modelled surface $\mathrm{O}_{3}$ fields have been compared to observations from various measurement sites (Dentener et al., 2006a). In all these studies, the ensemble mean was among the best when comparing to measurements. In this study we build on the model evaluation work listed above as well as on the individual evaluation of the models and make the assumption that the models produce reasonable simulations of the key chemical species. We use the ensemble mean to assess large-scale chemistry effects resulting from ship emissions for the present day and in the future.

In addition to the above mentioned studies, we evaluate here the models' ability to simulate $\mathrm{O}_{3}, \mathrm{NO}_{\mathrm{x}}$ and $\mathrm{SO}_{2}$ in the lower troposphere $(<3 \mathrm{~km})$ as well as tropospheric $\mathrm{NO}_{2}$ columns over the ocean by comparing the results from the S1 present-day reference simulations of the individual models to aircraft measurements (Emmons et al., 2000; Singh et al., 2006) and to satellite data from SCIAMACHY (Richter et al., 2004).

Tropospheric data from a number of aircraft campaigns have been gridded onto a $5^{\circ}$ longitude by $5^{\circ}$ latitude grid by Emmons et al. (2000), with additional data from more recent campaigns (see http://gctm.acd.ucar.edu/data), up to and including TRACE-P in 2001 (we subsequently refer to this data as "Emmons et al. (2000) plus updates"). We compare data over the Northern Hemisphere $\left(25^{\circ}-60^{\circ} \mathrm{N}\right)$ oceanic regions in Fig. 2. Most models reproduce the observed annual and seasonal $\mathrm{O}_{3}$ means in the lower troposphere $(<3 \mathrm{~km})$. Two models (GMI/CCM3 and GMI/DAO) simulate $\mathrm{O}_{3}$ values larger than observed in autumn and winter, and MATCHMPIC overestimates observed $\mathrm{O}_{3}$ in winter. The oceanic $25^{\circ}-60^{\circ} \mathrm{N}$ means in observations and models shown in Fig. 2 are averages over only those grid boxes that include observations for the particular species (see Fig. 3). To compare model results with observations in the Pacific and Atlantic, we use data collected during the INTEX-NA campaign in July/August 2004 in addition (see http://www-air.larc.nasa. gov/; Singh et al., 2006). The good agreement between modelled and observed $\mathrm{O}_{3}$ in July holds for both the Pacific and the Atlantic (Fig. 4).

In winter and autumn, the two STOCHEM models, both using the same chemistry scheme, simulate the highest $\mathrm{NO}_{\mathrm{x}}$ values among all models (Fig. 2). An additional analysis showed that in these models in these seasons, high $\mathrm{NO}_{\mathrm{x}}$ plumes from land-based anthropogenic sources were extending sufficiently far out to sea to affect the nearest oceanic data comparison points. In addition, the treatment of heterogeneous $\mathrm{NO}_{\mathrm{x}}$ loss in the STOCHEM models is very simple, and may be leading to unrealistically long $\mathrm{NO}_{\mathrm{x}}$ lifetimes in winter and autumn. For all other models the simulated $\mathrm{NO}_{\mathrm{x}}$ and $\mathrm{NO}_{2}$ (not shown) lies within one standard deviation $(1 \sigma)$ of the observational mean in all seasons with values above the observational mean in autumn and below in all other seasons as well as in the annual mean (Fig. 2). Nearly all observations for $\mathrm{NO}_{\mathrm{x}}$ over the Northern Hemisphere oceanic regions below $3 \mathrm{~km}$ in the Emmons et al. (2000) plus updates data set are made over the Pacific (Fig. 3). Compared to the INTEX-NA campaign, the simulated $\mathrm{NO}_{2}$ lies within $1 \sigma$ of the observational mean over the Atlantic and the Pacific (Fig. 4). This overall reasonable agreement between models and observations for $\mathrm{NO}_{\mathrm{x}}$ and $\mathrm{NO}_{2}$ differs from the findings of Kasibhatla et al. (2000) and Davis et al. (2001), who found that their models overpredicted $\mathrm{NO}_{\mathrm{x}}$ in the Atlantic and Pacific marine boundary layer. These authors used similar ship emissions, but compared with somewhat different observational data. Kasibhatla et al. (2000) used NARE campaign data from the North Atlantic $\left(37^{\circ}-50^{\circ} \mathrm{N} ; 35^{\circ}-50^{\circ} \mathrm{W}\right)$ in September 1997 and Davis et al. (2001) used data from five campaigns over the North Pacific.

$\mathrm{SO}_{2}$ in the four models that included a sulphur cycle generally lie within $1 \sigma$ of the observations in Fig. 2, but there is little data outside the winter season, and the standard deviations in the marine boundary layer are large, making it difficult to assess the models. One of the models (STOCHEMHadAM3) is consistently high, particularly in the free troposphere - this is probably related to the relatively large magnitude and elevated source of volcanic $\mathrm{SO}_{2}$ in this model. Standard deviations are smaller in the summertime INTEXNA data set over the Pacific (Fig. 4). All models significantly underestimate observed $\mathrm{SO}_{2}$ in July, in agreement with previous findings (Davis et al., 2001)

Kasibhatla et al. (2000) and Davis et al. (2001) suggested 
INTEX-NA, Atlantic $\left(60^{\circ} \mathrm{W}-36^{\circ} \mathrm{W}, 2^{\circ} \mathrm{N}-53^{\circ} \mathrm{N}\right)$

$\mathrm{O}_{3}$

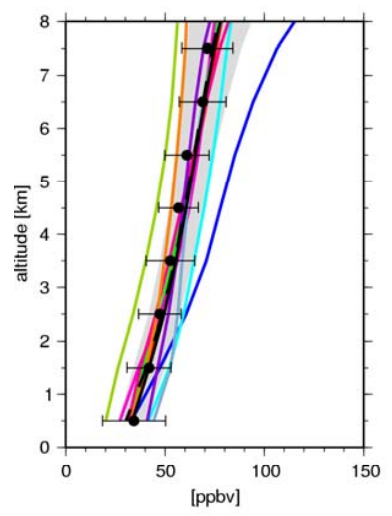

$\mathrm{NO}_{2}$

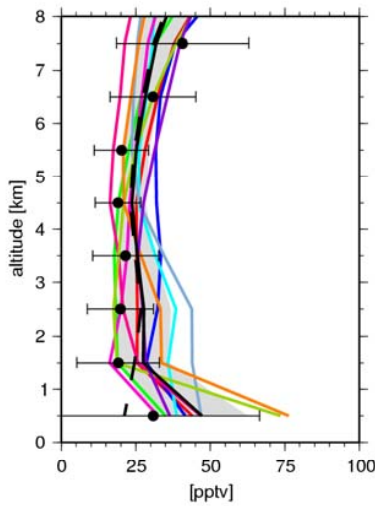

$\mathrm{SO}_{2}$

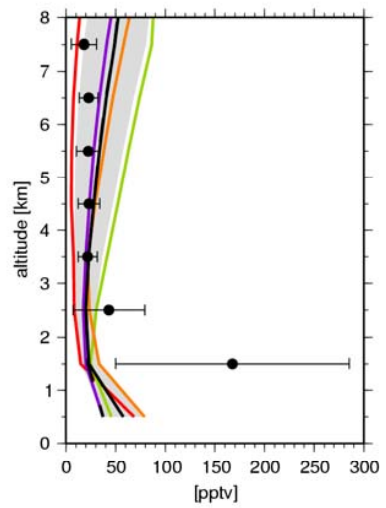

INTEX-NA, Pacific $\left(140^{\circ} \mathrm{W}-126^{\circ} \mathrm{W}, 34^{\circ} \mathrm{N}-45^{\circ} \mathrm{N}\right)$

$\mathrm{O}_{3}$

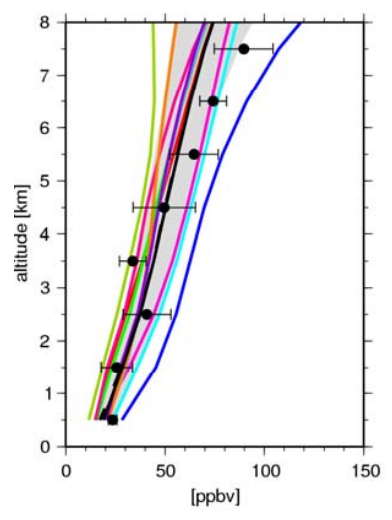

$\longmapsto-1 N T E X-N A$, mean

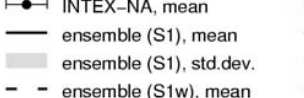

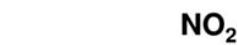

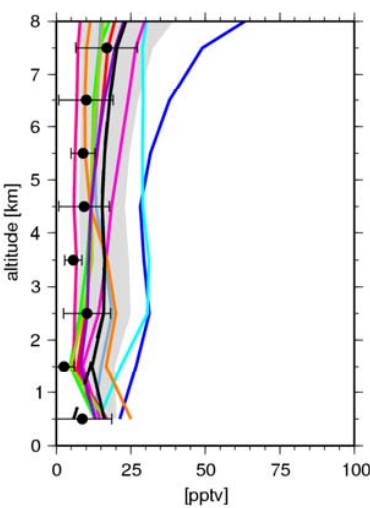

- CHASER-CTM

- FRSGC/UCI

- $\mathrm{GMI} / \mathrm{CCM} 3$

GMI/DAO

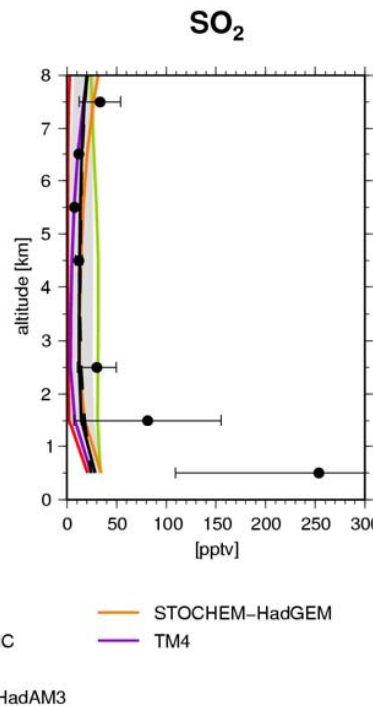

Fig. 4. Observations from the INTEX-NA campaign from 1 July to 15 August 2004 (Singh et al., 2006) compared to the July mean of the $\mathrm{S} 1$ model simulations for $\mathrm{O}_{3}$ (left), $\mathrm{NO}_{2}$ (middle), and $\mathrm{SO}_{2}$ (right) over the Atlantic (upper row, $60^{\circ} \mathrm{W}-36^{\circ} \mathrm{W}, 28^{\circ} \mathrm{N}-53^{\circ} \mathrm{N}$ ) and the Pacific (lower row, $140^{\circ} \mathrm{W}-126^{\circ} \mathrm{W}, 34^{\circ} \mathrm{N}-45^{\circ} \mathrm{N}$ ). The ensemble mean for $\mathrm{S} 1$ (all models) is shown as solid black line and for $\mathrm{S} 1 \mathrm{w}$ as dashed black line. The intermodel standard deviation for the $\mathrm{S} 1$ ensemble mean is shown as grey shaded areas, and the observations as filled black circles (mean) and black error bars (standard deviation).

that ship plume chemistry may partly explain the discrepancy between observed and simulated $\mathrm{NO}_{\mathrm{x}}$. While the neglect of ship plume chemistry in global models might contribute to differences between observations and models, we show here that the selection of data the models are compared to is also very important: if we reduce the Emmons et al. (2000) plus updates and the INTEX-NA data set and only compare the model results for $\mathrm{NO}_{\mathrm{x}}$ with the data used in Davis et al. (2001) we can reproduce their results. However, if we use the entire observational data set (Fig. 2), which is more widespread and therefore more robust (up to 32 campaigns between 1983 and 2001, including the five Pacific datasets, but not including the Atlantic NARE data) we find good agreement with observed $\mathrm{NO}_{\mathrm{x}}$. In addition, differences in the modelled and observed $\mathrm{NO}_{\mathrm{x}}$ and $\mathrm{SO}_{2}$ fields can not be fully attributed to ship emissions. In particular, the comparison with the Emmons et al. (2000) plus updates and the INTEX-NA data sets leads to only small differences between the S1 and the S1w ensemble mean (Figs. 2 and 4), so that the shipping signal cannot be properly evaluated. Therefore, it remains unclear whether the underestimation of $\mathrm{SO}_{2}$ in the marine boundary layer in the models is due to the ship emission inventory or due to the underestimation of another source (e.g. DMS), overestimation of a sink (e.g. oxidation), 


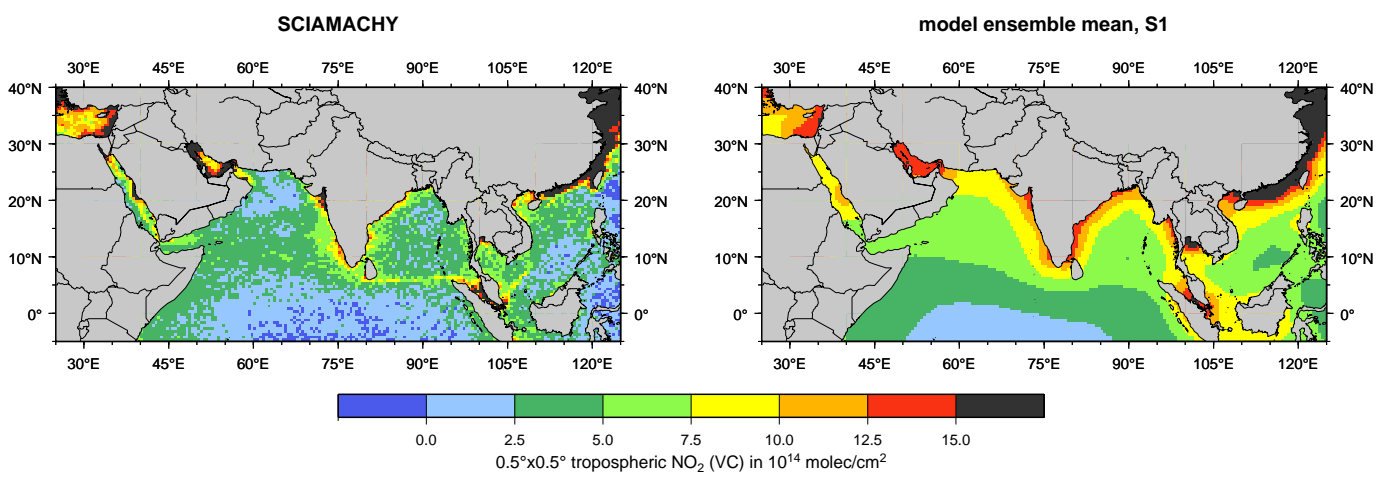

Fig. 5. $\mathrm{NO}_{\mathrm{X}}$ signature of shipping in the Indian Ocean $\left(5^{\circ} \mathrm{S}\right.$ to $40^{\circ} \mathrm{N}$ and $25^{\circ} \mathrm{E}$ to $\left.125^{\circ} \mathrm{E}\right)$. Left: Tropospheric $\mathrm{NO}_{2}$ columns derived from SCIAMACHY data from August 2002 to April 2004 (Richter et al., 2004). Right: Ensemble mean $\mathrm{NO}_{2}$ tropospheric columns at 10.30 local time for 2000. The ensemble mean comprises 8 out of the 10 models. Individual model results and SCIAMACHY data were interpolated to a common grid $\left(0.5^{\circ} \times 0.5^{\circ}\right)$.

errors associated with simulating specific events (e.g. horizontal/vertical transport and mixing), or a combination of several factors. More measurements are needed before final conclusions on the quality of the models to simulate the ship emission response can be made (see also Sect. 5).

Another approach to evaluate the shipping response in models is the use of satellite data. Recently, enhanced tropospheric $\mathrm{NO}_{2}$ columns have been observed over the Red Sea and along the main shipping lane to the southern tip of India, to Indonesia and north towards China and Japan (Beirle et al., 2004; Richter et al., 2004). Here we intercompare the tropospheric $\mathrm{NO}_{2}$ columns derived from SCIAMACHY nadir measurements from August 2002 to April 2004 (Richter et al., 2004) to the models' ensemble mean in 2000 (S1 simulation). The ensemble mean in Fig. 5 consists of the eight models that provided tropospheric $\mathrm{NO}_{2}$ columns at 10:30 a.m. local time, which is close to the overpass time of the ERS-2 satellite. The two STOCHEM models provided output only as $24 \mathrm{~h}$ mean, and are not included. To compare the model data to the satellite measurements, individual model results and SCIAMACHY data were interpolated to a common grid $\left(0.5^{\circ} \times 0.5^{\circ}\right)$. The models simulate similar tropospheric $\mathrm{NO}_{2}$ columns over the remote ocean as observed by SCIAMACHY and also reproduce the overall pattern of the geographical distribution reasonably well. However, although the shipping signal is clearly visible in the satellite data it is not resolved by the models, because the intercomparison of modelled and observed $\mathrm{NO}_{2}$ columns is complicated by several factors. First of all, the spatial resolution of the SCIAMACHY measurements $\left(30 \times 60 \mathrm{~km}^{2}\right)$ is much higher than that of the global models (typically $5^{\circ} \times 5^{\circ}$ ) leading to higher $\mathrm{NO}_{2}$ values in the localized plumes from ship emissions. Secondly, in the particular scene shown in Fig. 5, shipping routes are rather close to land. Given the low resolution of the models, the grid boxes close to the coast are dominated by $\mathrm{NO}_{\mathrm{x}}$ emissions from land sources which are much stronger than emissions from shipping. Thus, the shipping signal cannot be identified in the coarse resolution model data in this region. From this point of view, an intercomparison over the remote ocean (e.g. over the Atlantic) with satellite data far away from any land source would be preferable. However, up to now, no statistically significant satellite data on ship emissions are available for remote oceans. This is mainly due to the distributed nature of the emissions which leads to dilution and makes it difficult to distinguish the shipping signal from the effect of long-range transport from the US towards Europe. Increasing ship emission in the future should make detection possible, in particular if data from an instrument with good spatial coverage such as OMI or GOME-2 is used in combination with model calculations of the contribution of long range transport. However, unambiguous identification and quantification will always be more difficult than in the special case between India and Indonesia with its unique emission pattern.

\subsection{Large-scale chemistry effects of $\mathrm{NO}_{\mathrm{x}}$ ship emissions in 2000}

To examine the range of results given by the individual models compared to the ensemble mean, Fig. 6 shows differences in annually averaged zonal mean $\mathrm{O}_{3}$ versus height between the 2000 base case simulation (S1) and the model simulation without shipping (S1w) for each model and the ensemble mean. Standard deviations are shown in addition indicating regions of large intermodel variability. All models show the maximum contributions from ships in zonal annual mean near-surface $\mathrm{O}_{3}$ in northern mid-latitudes between $10^{\circ} \mathrm{N}$ and $55^{\circ} \mathrm{N}$, where most of the global ship emissions are released into the atmosphere (see Fig. 1). A rapid decrease of the impact on $\mathrm{O}_{3}$ distributions with height is simulated. There are notable differences in the magnitude of the response to ship emissions between the individual models which can be attributed to differences in the main 

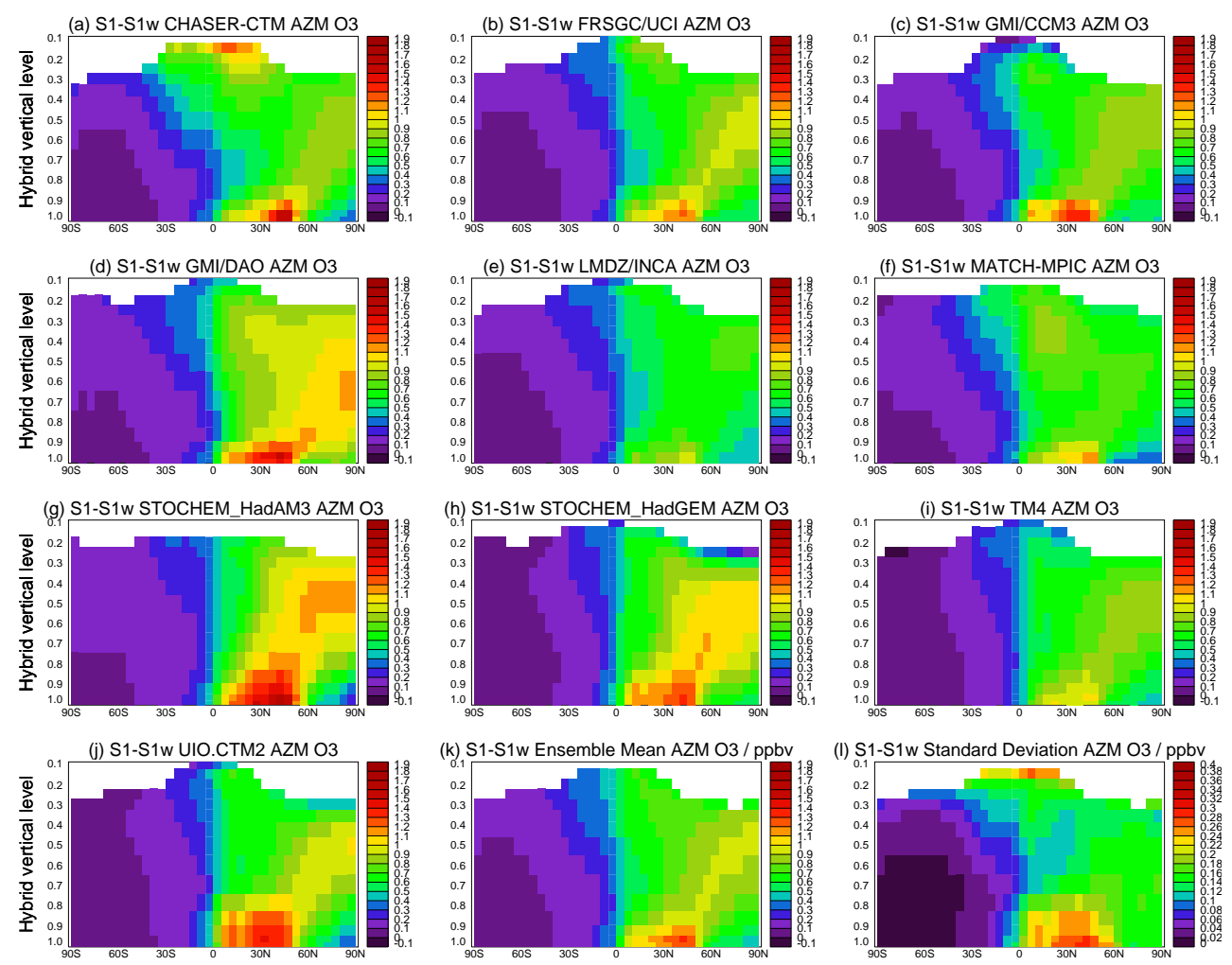

Fig. 6. Modelled zonal annual mean $\mathrm{O}_{3}$ change (ppbv) between case $\mathrm{S} 1$ (year 2000) and $\mathrm{S} 1 \mathrm{w}$ (year 2000 without ship emissions): (a-j) individual models (k) ensemble mean (all 10 models) and (l) intermodel standard deviations. Individual model results were interpolated to a common grid $\left(5^{\circ} \times 5^{\circ} \times 19\right.$ levels $)$ and masked at the chemical tropopause $\left(\mathrm{O}_{3}=150 \mathrm{ppbv}\right)$.

characteristics of the models (see Sect. 2.1). The two models that show the strongest response of $\mathrm{O}_{3}$ to ship emissions are the UIO.CTM2 and the STOCHEM-HadAM3 models. The models with the weakest response are the LMDz/INCACTM and the TM4 models. Previous studies reported that the production of $\mathrm{O}_{3}$ depends on the resolution of the model with models having higher resolution simulating less $\mathrm{O}_{3}$ production than those with a coarser resolution (e.g. Esler, 2003; Wild and Prather, 2006). However, there are large differences in the responses of the UIO.CTM2, CHASER and FRSGC/UCI models, all running at the highest resolution used here $\left(2.8^{\circ} \times 2.8^{\circ}\right)$, while the MATCH-MPIC model running at the coarsest horizontal resolution $\left(5.6^{\circ} \times 5.6^{\circ}\right)$ has a low $\mathrm{O}_{3}$ response. It is therefore clear that factors other than resolution play an important role in explaining the differences (see Sect. 2.1). The ensemble mean shows the largest increase in near-surface zonal mean $\mathrm{O}_{3}$ due to ships of up to $1.3 \mathrm{ppbv}$ in northern mid-latitudes with intermodel differences around $20 \%$ (Fig. 6k,l). In the free troposphere at latitudes further north changes still reach $1 \mathrm{ppbv}$ with intermodel differences of around $0.16 \mathrm{ppbv}(16 \%)$. In the Southern Hemisphere no significant changes in zonal mean $\mathrm{O}_{3}$ distribution are simulated by all models. We conclude that the range of results given by the individual models in- dicates uncertainties of the presented ensemble means of the order of $20 \%$ near the surface and slightly lower in the free troposphere. The high standard deviations in the tropical tropopause layer are caused by a single model (CHASER). The main conclusions in the subsequent sections are based on the models' ensemble mean.

Due to the short lifetime of $\mathrm{NO}_{2}$ in the boundary layer, near-surface changes in $\mathrm{NO}_{2}$ due to ship emissions ( $\mathrm{S} 1-\mathrm{S} 1 \mathrm{w}$ ) follow closely the main shipping routes, but the dispersion is a few hundred kilometres, which is partly due to coarse resolutions of the models, but also real transport (Fig. 7). Maximum changes of 2.3 ppbv are found over the Baltic Sea in both months. In the English Channel and along the west coast of Europe (from Ireland to Morocco) $\mathrm{NO}_{2}$ changes are also significant (around $0.5 \mathrm{ppbv}$ ). Enhanced $\mathrm{NO}_{2}$ levels up to $0.2 \mathrm{ppbv}$ are also simulated over large areas of the Atlantic and e.g. in the Red Sea and along the main shipping lane to the southern tip of India, to Indonesia and north towards China and Japan as well as in the Gulf of Mexico. In July $\mathrm{NO}_{2}$ changes over the Baltic and over the Atlantic are smaller than in January and cover a smaller area, as the lifetime of $\mathrm{NO}_{\mathrm{x}}$ in the summer months is shorter due to higher chemical activity. Relative changes in $\mathrm{NO}_{2}$ strongly depend on the level of $\mathrm{NO}_{\mathrm{x}}$ from other sources. For example, even 

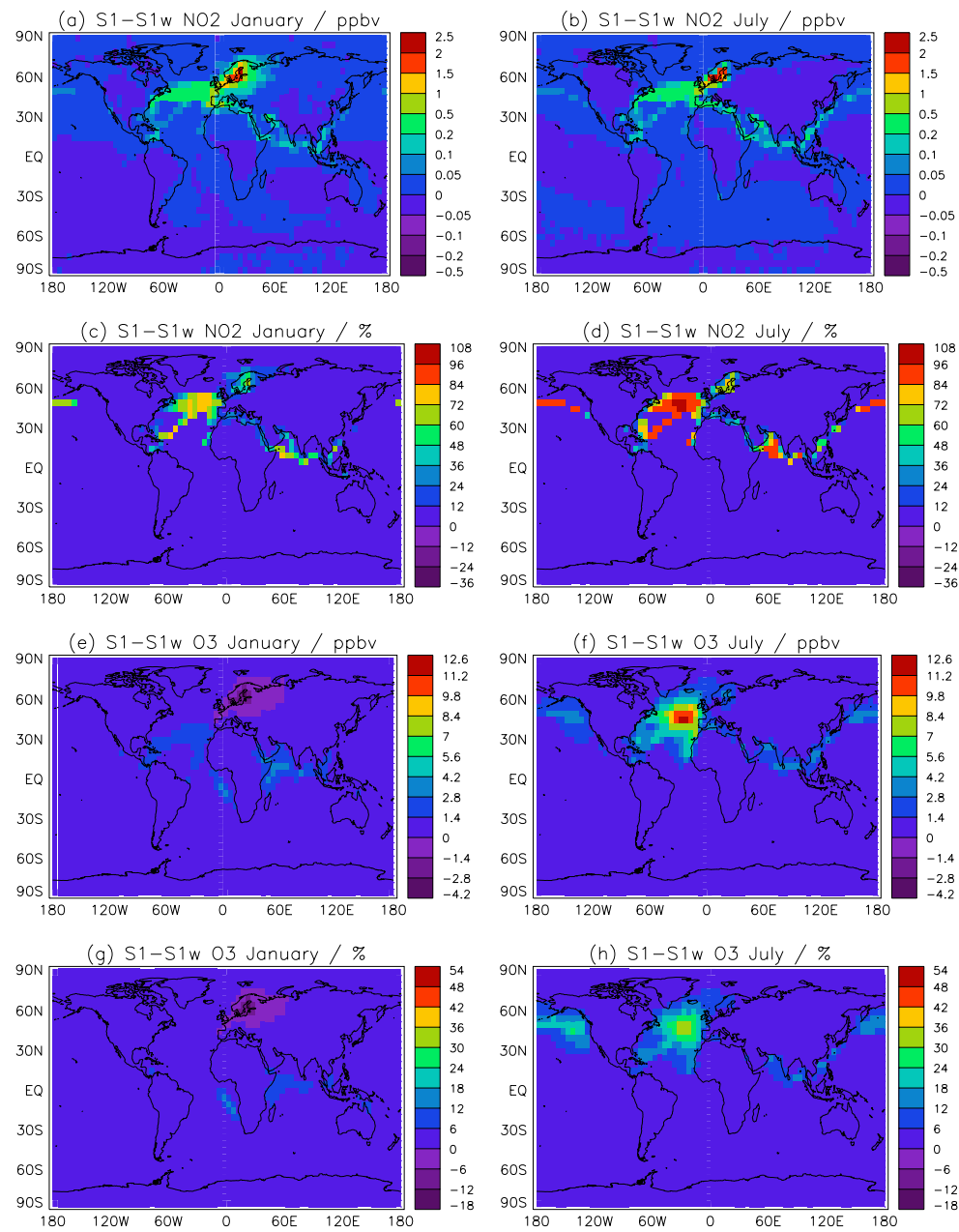

Fig. 7. Modelled ensemble mean near-surface $\mathrm{NO}_{2}$ and $\mathrm{O}_{3}$ change between case $\mathrm{S} 1$ (year 2000) and $\mathrm{S} 1 \mathrm{w}$ (year 2000 without ship emissions) in January (left) and July (right). (a-b): absolute changes in near-surface $\mathrm{NO}_{2} ;(\mathbf{c}-\mathbf{d})$ : relative changes in near-surface $\mathrm{NO}_{2} ;(\mathbf{e}-\mathbf{f})$ absolute changes in near-surface $\mathrm{O}_{3} ;(\mathbf{g}-\mathbf{h})$ : relative changes in near-surface $\mathrm{O}_{3}$.

though absolute $\mathrm{NO}_{2}$ changes over the Baltic and the North Sea are large, relative changes are less pronounced because of high background $\mathrm{NO}_{2}$ levels. The largest relative changes of up to $80 \%$ in January and $96 \%$ in July are found over the remote Atlantic and along the major shipping lanes, where background levels are small and $\mathrm{NO}_{\mathrm{x}}$ emissions from ships are the dominant source (see Fig. 1).

Substantial differences are simulated between the nearsurface January and July ensemble mean $\mathrm{O}_{3}$ changes despite the fact that there are no seasonal variations in the ship emission inventory (Fig. 7, lower panels). The reason for the difference is that during winter additional $\mathrm{NO}_{\mathrm{x}}$ emissions from shipping can lead to $\mathrm{O}_{3}$ titration in the highly polluted regions over the continents, whereas in summer the additional $\mathrm{NO}_{\mathrm{x}}$ leads to $\mathrm{O}_{3}$ production. $\mathrm{O}_{3}$ concentrations in January show a decrease of around $1 \mathrm{ppbv}$ with maximum decreases of up to $2.8 \mathrm{ppbv}$ over the Baltic. The changes in July over this region are rather small but positive. The largest increases in January are found southward of $30^{\circ} \mathrm{N}$, where the available solar radiation is sufficient for $\mathrm{O}_{3}$ production to outweigh direct removal of NO. Most pronounced increases of $3.3 \mathrm{ppbv}$ are simulated over the Indian Ocean and along the main shipping lane west of the coast of Southern Africa. The simulated large decrease in $\mathrm{O}_{3}$ over a large area in Europe in winter, which has not been reported in e.g. the Endresen et al. (2003) study, might be due to high vessel traffic densities in particular over the Baltic Sea in the inventory used here. Vessel traffic densities derived from different sources such as AMVER (Automated Mutual-assistance Vessel Rescue system) or the Purple Finder (PF) data set (available at http://www.purplefinder.com) report fewer observations there (Endresen et al., 2003), see further discussion in Sect. 4.1.1. In July, the geographical pattern in $\mathrm{O}_{3}$ changes is similar to the pattern in Lawrence and Crutzen (1999) showing most pronounced changes over wide areas of the Atlantic up to $12 \mathrm{ppbv}$ (approx. 35\%) and over the 

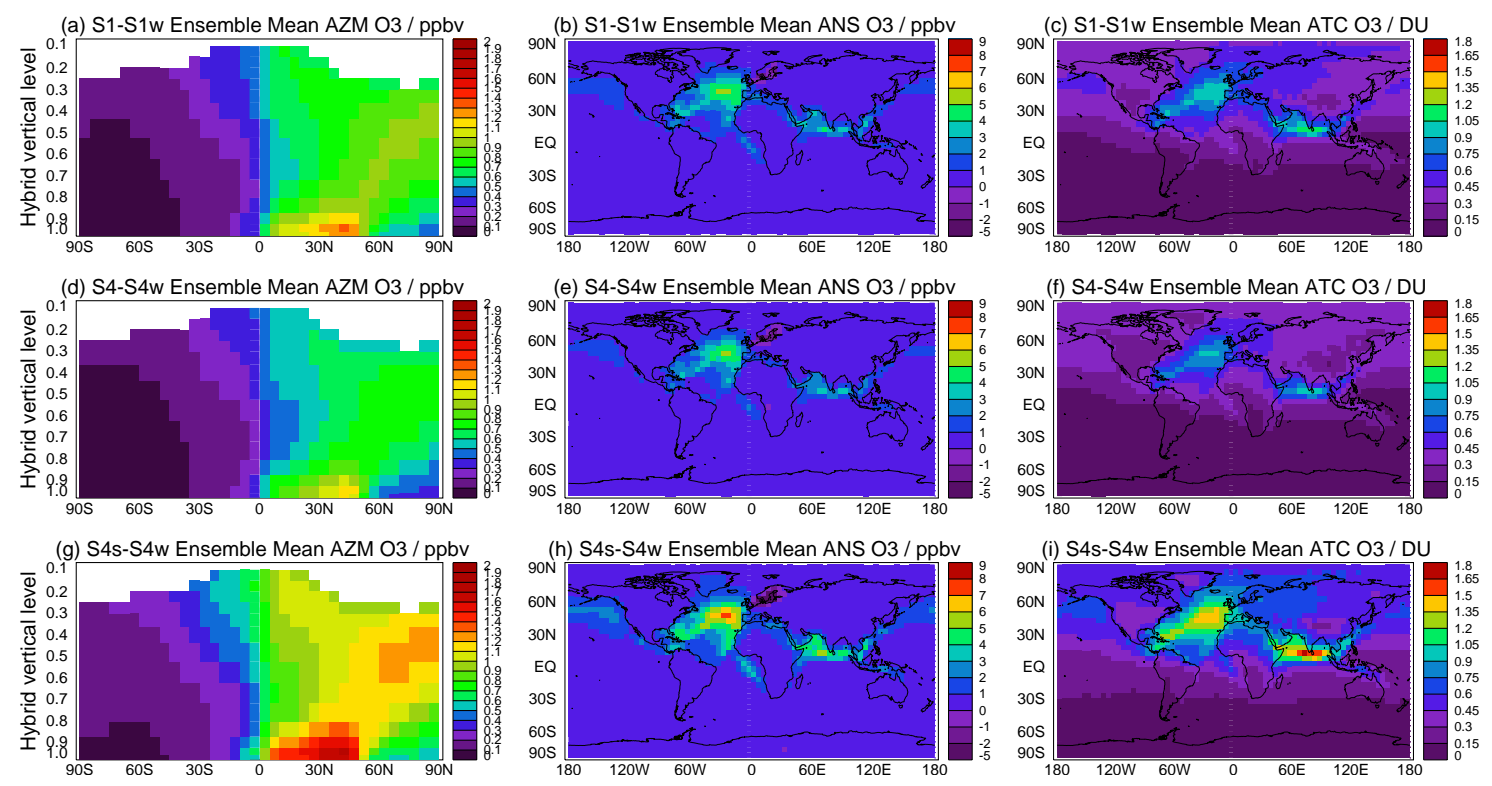

Fig. 8. Modelled ensemble mean $\mathrm{O}_{3}$ change between (a-c) case $\mathrm{S} 1$ (year 2000) and $\mathrm{S} 1 \mathrm{w}$ (year 2000 without ship emissions), (d-f) case S4 (year 2030) and S4w (year 2030 without ship emissions), and (g-i) case S4s (year 2030) and S4w. Figures 8a, 8d, and 8g are zonal mean changes (ppbv), Figs. 8b, 8e, and $8 \mathrm{~h}$ are near-surface $\mathrm{O}_{3}$ changes (ppbv) and Figs. 8c, 8f, and $8 \mathrm{i}$ are tropospheric $\mathrm{O}_{3}$ column changes (DU).

Western and Northern Pacific up to 5 ppbv (approx. 25\%). Changes of the order of 5 ppbv (approx. 10\%) are also simulated over the Indian Ocean. The simulated changes over the Atlantic and the Indian Ocean are in good agreement with results reported in Endresen et al. (2003), but smaller over the Pacific. Differences between the two studies are likely related to the difference in vessel traffic densities (see Sect. 4.1.1). Due to the longer lifetime of $\mathrm{O}_{3}$ compared to $\mathrm{NO}_{2}$ in the boundary layer, $\mathrm{O}_{3}$ changes are less strictly confined to the main shipping lanes, and thus affect larger areas. Non-linear effects of $\mathrm{O}_{3}$ photochemistry are significant. For example, over the Baltic and the North Sea, where background $\mathrm{NO}_{2}$ levels are relatively high, changes in $\mathrm{O}_{3}$ are comparatively small, whereas they are substantial over more remote areas.

\subsection{Large-scale chemistry effects of $\mathrm{NO}_{\mathrm{x}}$ ship emissions in 2030}

\subsubsection{Ozone distributions}

Figure 8 shows modelled ensemble mean $\mathrm{O}_{3}$ changes due to ship emissions for the year 2000 (S1-S1w) and for two different scenarios in 2030 (S4-S4w; S4s-S4w). As vessel traffic densities are the same in all model simulations the 2030 results mainly show a scaling of the 2000 results, but nonlinearity effects also play a role. $\mathrm{O}_{3}$ changes versus height in 2000 (Fig. 8a) have already been discussed in Sect. 3.1. The largest $\mathrm{O}_{3}$ response is found near the surface between $10^{\circ}-$ $55^{\circ} \mathrm{N}$, and rapidly decreases with altitude. Keeping emis- sions from shipping at 2000 levels but with all other emissions increasing, the pattern in zonal mean changes remains the same but the impact is slightly less than in 2000 due to lower $\mathrm{O}_{3}$ production rates under the influence of higher background of $\mathrm{NO}_{\mathrm{x}}$ concentrations (Fig. 8d; S4-S4w). Under the $\mathrm{S} 4 \mathrm{~s}$ scenario near-surface $\mathrm{O}_{3}$ changes of about $1.7 \mathrm{ppbv}$ are simulated in the zonal mean between $10^{\circ}-55^{\circ} \mathrm{N}$, and even in the free troposphere changes in $\mathrm{O}_{3}$ reach up to $1.3 \mathrm{ppbv}$ (Fig. 8g). Changes in the annual mean near-surface level reach $5.5 \mathrm{ppbv}$ over the Atlantic (Fig. 8b) and increase up to $7.4 \mathrm{ppbv}$ in the S4s scenario in 2030 (Fig. 8h). Over Northern Europe where there are high levels of $\mathrm{NO}_{\mathrm{x}}$, the increase in $\mathrm{NO}_{\mathrm{x}}$ from shipping decreases, rather than increases, $\mathrm{O}_{3}$ levels. This is due to reduction in oxidant levels as $\mathrm{OH}$ is removed by the reaction $\mathrm{NO}_{2}+\mathrm{OH}->\mathrm{HNO}_{3}$, and in winter to direct titration of $\mathrm{O}_{3}$ by $\mathrm{NO}_{2}$. The effect is stronger in the 2030 scenarios due to the increased background level of $\mathrm{NO}_{\mathrm{x}}$ in Northern Europe, with shipping decreasing $\mathrm{O}_{3}$ by $3 \mathrm{ppbv}$ in the S4s scenario.

The most pronounced changes in tropospheric $\mathrm{O}_{3}$ columns are found over the Indian Ocean (1.16 DU in 2000 and 1.72 DU in 2030), related to the higher tropopause there and to more effective transport of $\mathrm{O}_{3}$ from the boundary into the upper troposphere. A second peak is simulated over the Atlantic (Figs. 8c,f,i). 
$\Delta \mathrm{NO}_{\times}$(global)

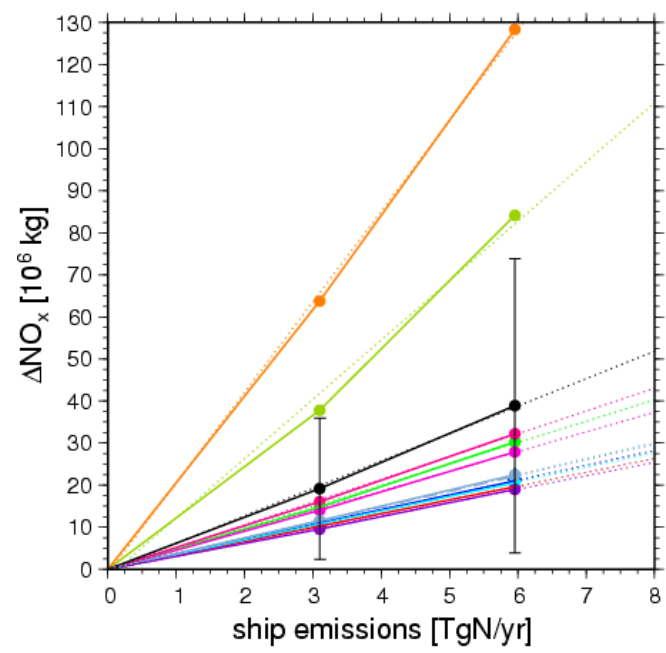

$\Delta \mathrm{O}_{3}$ (global)

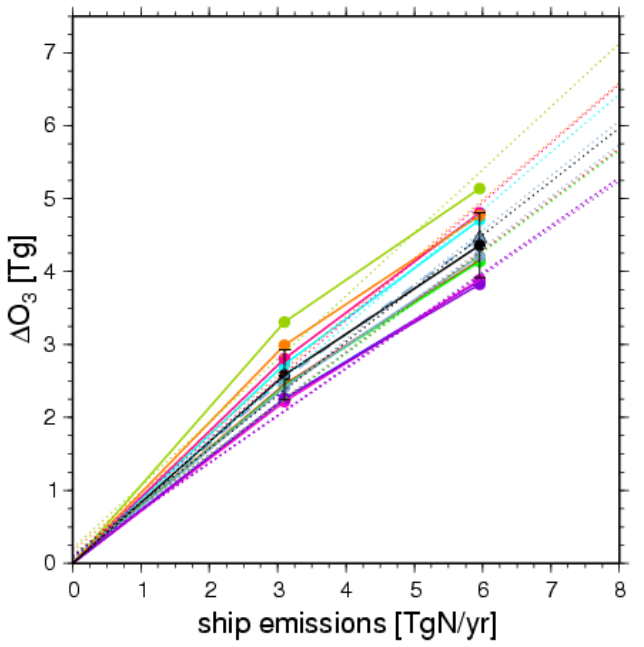

$\longrightarrow$ UIO.СTM2

$\longrightarrow$ STOCHEM-HadAM

$\longrightarrow$ STOCHEM-HadGEM

$\bullet$ TMA

Fig. 9. Global total change in annual mean tropospheric $\mathrm{NO}_{\mathrm{x}}$ burden (left) and $\mathrm{O}_{3}$ burden (right) due to ship emissions (S4-S4w and $\mathrm{S} 4 \mathrm{~s}-$ $\mathrm{S} 4 \mathrm{w}$ ) in each individual model (coloured lines) and the ensemble mean (black line). Inter-model standard deviations are shown as black bars.

\subsubsection{Linearities in $\mathrm{NO}_{\mathrm{x}}$ and $\mathrm{O}_{3}$ burden response to ship emissions}

Changes in annual mean $\mathrm{NO}_{\mathrm{x}}$ and $\mathrm{O}_{3}$ burdens are calculated for the two 2030 scenarios (S4-S4w; S4s-S4w) as described in Sect. 2.3 for four different regions (global mean, Atlantic Ocean, Baltic Sea, and Indian Ocean). A linear regression is performed for the changes in $\mathrm{NO}_{\mathrm{x}}$ and $\mathrm{O}_{3}$ burdens due to shipping over the scenarios S4-S4w, S4s-S4w and the origin (zero $\mathrm{NO}_{\mathrm{x}}$ ship emissions / zero changes in $\mathrm{NO}_{\mathrm{x}}$ and $\mathrm{O}_{3}$ burdens). The changes in global tropospheric $\mathrm{NO}_{\mathrm{x}}$ burden associated with these two scenarios show a fairly linear relationship for all models (Fig. 9, left), and a doubling of $\mathrm{NO}_{\mathrm{x}}$ emissions approximately results into a doubling of the mean $\mathrm{NO}_{\mathrm{x}}$ burden.

For $\mathrm{O}_{3}$ the correlation is also broadly linear (Fig. 9, right). Only small saturation effects are visible as the $\mathrm{O}_{3}$ burden for the low emission scenario $(3.10 \mathrm{Tg}(\mathrm{N}))$ lies slightly above the multi-regression line whereas the one for the high emission scenario $(5.95 \operatorname{Tg}(\mathrm{N}))$ lies slightly below the multi-regression line for all models. This is to be expected due to nonlinearities in the $\mathrm{O}_{3}$ chemistry. In contrast to the relatively small degree of saturation computed here, Labrador et al. (2004) computed a substantial saturation effect for lightning $\mathrm{NO}_{\mathrm{x}}$ emissions as they were increased from 0 to $20 \mathrm{Tg}(\mathrm{N}) / \mathrm{yr}$, with the saturation already becoming clearly evident between 5 and $10 \operatorname{Tg}(\mathrm{N}) / \mathrm{yr}$. Although there are only three data points available here $(0,3.1$ and $5.95 \operatorname{Tg}(\mathrm{N}) / \mathrm{yr})$, there is evidence in these results that the ship $\mathrm{NO}_{\mathrm{x}}$ effect is only weakly subject to saturation in its current magnitude range, and that saturation cannot be expected to help mitigate the effects of near-future increases. Overall, similar to $\mathrm{NO}_{\mathrm{x}}$ burdens, a doubling in $\mathrm{NO}_{\mathrm{x}}$ ship emissions results in approximately a doubling in $\mathrm{O}_{3}$ burdens in the ensemble mean. Note that, whereas the majority of the models (eight out of ten) show similar response, the two STOCHEM models simulate $\mathrm{NO}_{\mathrm{x}}$ burden changes around a factor of 3 (STOCHEM-HadAM3) or 6 (STOCHEM-HadGEM) higher than the other models, which explains the large standard deviations of the ensemble mean $\mathrm{NO}_{\mathrm{x}}$ burden. As discussed in Sect. 3.1, this can mainly be attributed to high $\mathrm{NO}_{\mathrm{x}}$ plumes from land-based anthropogenic sources and to the long $\mathrm{NO}_{\mathrm{x}}$ lifetimes in winter and autumn in these two models. For the annual $\mathrm{O}_{3}$ burdens the two STOCHEM models show similar results compared to all other models, and the inter-model standard deviations for $\mathrm{O}_{3}$ are small $(<15 \%)$.

Similar to the global annual burdens, eight out of the ten models show similar response in the seasonal cycle of $\mathrm{NO}_{\mathrm{x}}$ and $\mathrm{O}_{3}$ burden changes for the $\mathrm{S} 4 \mathrm{~s}-\mathrm{S} 4 \mathrm{w}$ scenario over the Atlantic Ocean, the Baltic Sea, the Indian Ocean and globally (Fig. 10). As expected, the seasonal cycle in both $\mathrm{NO}_{\mathrm{x}}$ and $\mathrm{O}_{3}$ is most pronounced in the Baltic Sea (northern hemispheric mid-latitudes), whereas the amplitude of the seasonal 
$\Delta \mathrm{NO}_{\times}(\mathrm{S} 4 \mathrm{~s}-\mathrm{S} 4 \mathrm{w})$
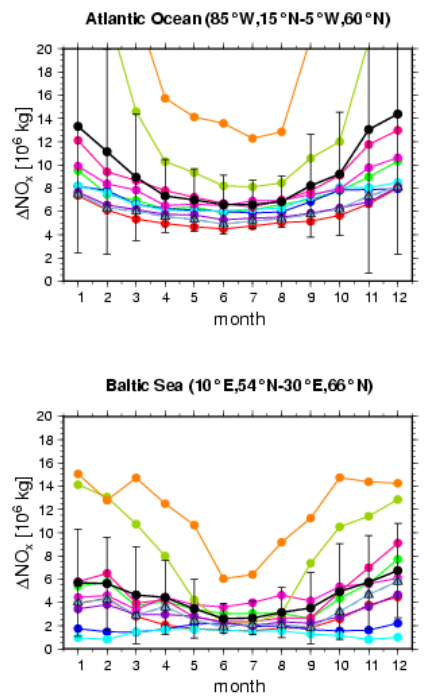

Indian Ocean $\left(50^{\circ} \mathrm{E}, 0^{\circ} \mathrm{N}-100^{\circ} \mathrm{E}, 25^{\circ} \mathrm{N}\right)$
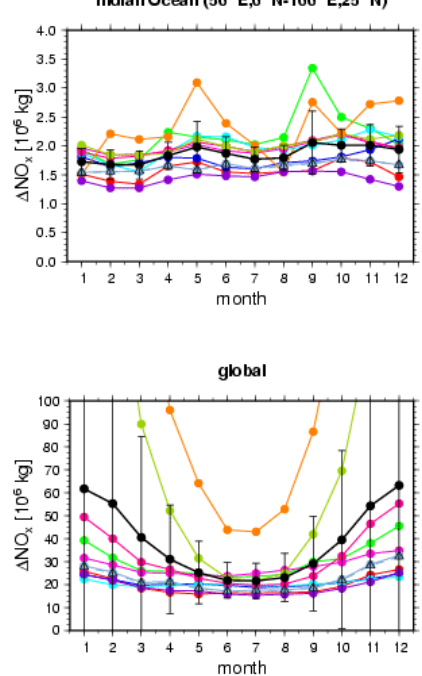

$\Delta \mathrm{O}_{3}(\mathrm{~S} 4 \mathrm{~s}-\mathrm{S} 4 \mathrm{w})$
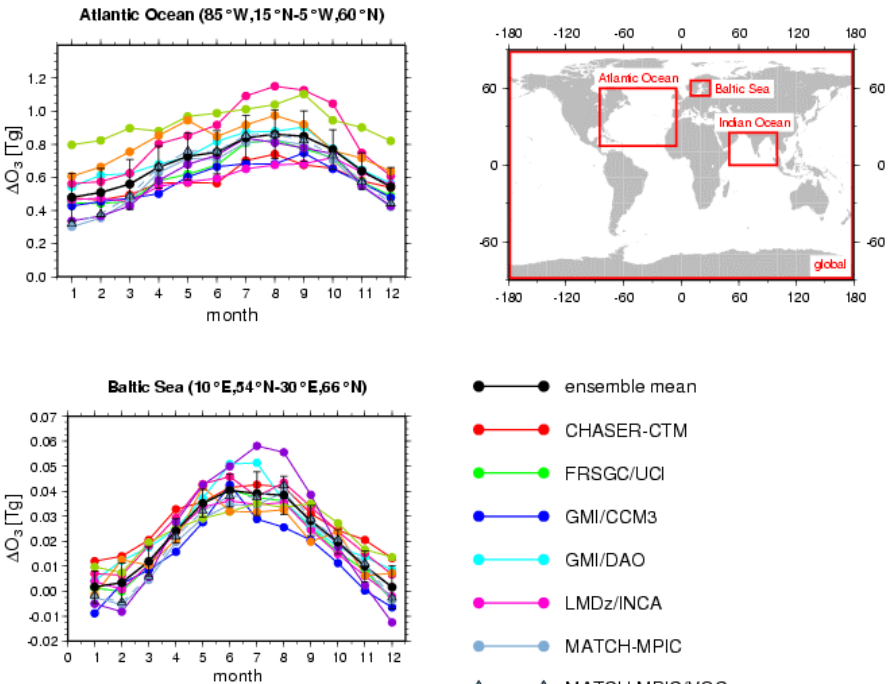

$\longrightarrow$ FRSGC/UCl

$\bullet \mathrm{GMI} / \mathrm{CCM} 3$

$\because$ GMI/DAO

$\bullet$ LMDz/INCA

$\bullet$ MATCH-MPIC

$\triangle--\triangle$ MATCH-MPIC/VOC

$\bullet$ UIO.CTM2

$\bullet$ STOCHEM-HadAM3

$\longrightarrow$ STOCHEM-HadGEM

$\bullet$ TM4

Fig. 10. Seasonal variation in tropospheric $\mathrm{NO}_{\mathrm{x}}$ (left column) and $\mathrm{O}_{3}$ (middle column) burden due to shipping for the scenario $\mathrm{S} 4 \mathrm{~s}-\mathrm{S} 4 \mathrm{w}$ in different regions: Atlantic Ocean $\left(85^{\circ} \mathrm{W}-5^{\circ} \mathrm{W} ; 15^{\circ} \mathrm{N}-60^{\circ} \mathrm{N}\right)$, Baltic Sea $\left(10^{\circ} \mathrm{E}-30^{\circ} \mathrm{E} ; 54^{\circ} \mathrm{N}-66^{\circ} \mathrm{N}\right)$, Indian $\mathrm{Ocean}\left(50^{\circ} \mathrm{E}-100^{\circ} \mathrm{E}\right.$; $0^{\circ} \mathrm{N}-25^{\circ} \mathrm{N}$ ) and global.

cycle over the Indian Ocean is relatively small. Again the two STOCHEM models show significantly higher changes in $\mathrm{NO}_{\mathrm{x}}$ burdens in winter and autumn in northern mid-latitude regions (Atlantic and Baltic Sea). The change in ensemble mean $\mathrm{O}_{3}$ burdens reaches peak values of about $0.8 \mathrm{Tg}$ over the Atlantic in August, $0.4 \mathrm{Tg}$ over the Indian Ocean in October, and $0.04 \mathrm{Tg}$ over the Baltic Sea in June. The global change in $\mathrm{NO}_{\mathrm{x}}$ burden due to ship emissions as simulated by the ensemble mean in the $\mathrm{S} 4 \mathrm{~s}$ scenario is enhanced by $25 \mathrm{Gg}$ in summer. The global $\mathrm{O}_{3}$ burden is enhanced by about $4 \mathrm{Tg}$ with peak changes in October and smallest changes in January.
3.4 Large-scale chemistry effects of $\mathrm{SO}_{2}$ ship emissions in 2000 and 2030

A subset of four models (CHASER, STOCHEM-HadAM3, STOCHEM-HadGEM, and TM4) included the tropospheric sulphur cycle. The ensemble mean of these four models has been applied to quantify changes due to shipping in sulphate distributions now and in the future (Fig. 11). Maximum changes due to shipping in the ensemble mean zonal mean sulphate $\left(\mathrm{SO}_{4}\right)$ distribution are located in the boundary layer of the northern mid-latitudes around $40^{\circ} \mathrm{N}$. These changes result in about 30 pptv in the year 2000 simulations 

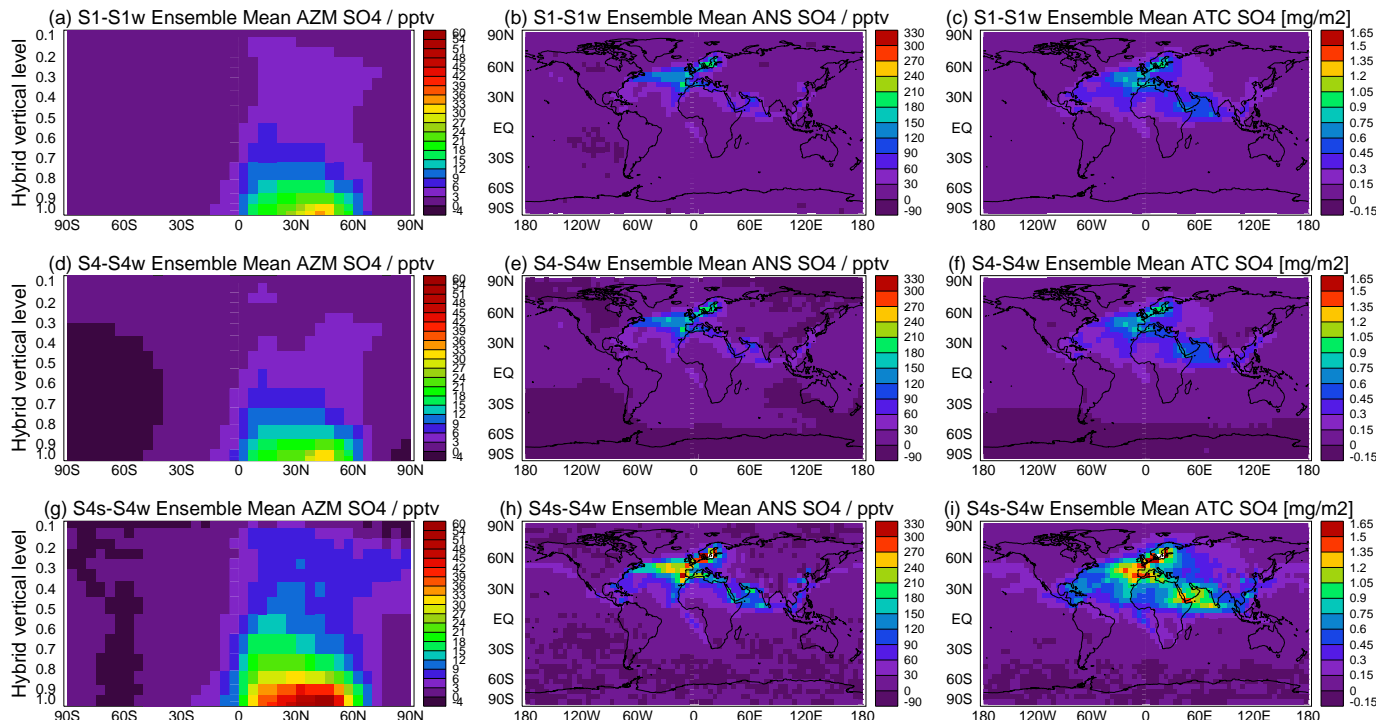

Fig. 11. Modelled ensemble mean tropospheric sulphate changes between (a-c) case S1 (year 2000) and S1w (year 2000 without ship emissions), (d-f) case S4 (year 2030) and S4w (year 2030 without ship emissions), and (g-i) case S4s (year 2030) and S4w. Figures 11a, $11 \mathrm{~d}$, and $11 \mathrm{~g}$ are zonal mean changes (pptv), Figs. 11b, 11e, and $11 \mathrm{~h}$ are near-surface sulphate changes (pptv) and Figs. 11c, 11f, and 11i are tropospheric sulphate column changes $\left(\mathrm{mg} / \mathrm{m}^{2}\right)$. Individual model results were interpolated to a common grid $\left(5^{\circ} \times 5^{\circ} \times 19\right.$ levels $)$ and masked at the chemical tropopause $\left(\mathrm{O}_{3}=150 \mathrm{ppbv}\right)$. The ensemble mean comprises four models.

Table 3. $\mathrm{O}_{3}, \mathrm{SO}_{4}, \mathrm{CO}_{2}$, and $\mathrm{CH}_{4}$ radiative forcings due to shipping in 2000 and 2030. The RF resulting from the indirect aerosol effect is not included but is expected to be negative and larger in magnitude than the direct sulphate effects estimated here (Capaldo et al., 1999). Ozone forcings include inter-model standard deviations, based on the ensemble of 10 models. Other forcings are rough central estimates with larger, less well constrained uncertainties, see Sect. 3.5.

\begin{tabular}{ccccc}
\hline & $\mathrm{O}_{3} \mathrm{~mW} / \mathrm{m}^{2}$ & $\mathrm{SO}_{4}$ (direct) $\mathrm{mW} / \mathrm{m}^{2}$ & $\mathrm{CH}_{4} \mathrm{~mW} / \mathrm{m}^{2}$ & $\mathrm{CO}_{2} \mathrm{~mW} / \mathrm{m}^{2}$ \\
\hline $2000(\mathrm{~S} 1-\mathrm{S} 1 \mathrm{w})$ & $9.8 \pm 2.0$ & -14 & -14 & 26 \\
$2030(\mathrm{~S} 4-\mathrm{S} 4 \mathrm{w})$ & $7.9 \pm 1.4$ & -13 & -13 & 24 \\
$2030(\mathrm{~S} 4 \mathrm{~s}-\mathrm{S} 4 \mathrm{w})$ & $13.6 \pm 2.3$ & -26 & -21 & 46 \\
\hline
\end{tabular}

and 50 pptv in the year $2030(\mathrm{~S} 4 \mathrm{~s}-\mathrm{S} 4 \mathrm{w})$. With increasing height, the changes in $\mathrm{SO}_{4}$ decrease continuously to about 35 pptv (2000) and 6-9 pptv (2030) in the upper troposphere. In the lowermost boundary layer over the Atlantic Ocean at the west coast of Europe and over the Baltic Sea, maximum annual sulphate changes amount to about 200 pptv in 2000 and 300 pptv in 2030 . The geographical pattern shows the main shipping routes over the Atlantic Ocean between Europe and North America and over the Red Sea and the Indian Ocean between the Arabian Peninsula and India. In all other parts of the world, changes in sulphate due to $\mathrm{SO}_{2}$ emissions from shipping remain low in general. Globally, shipping contributes with $4.5 \%$ to sulphate increases until 2030 under the A2/CGS.

\subsection{Radiative Forcing}

$\mathrm{O}_{3}$ distributions from all scenarios and all models were used as input for an offline radiation scheme (Edwards and Slingo, 1996), with all other parameters held constant, broadly representing the present-day atmosphere. In the stratosphere, $\mathrm{O}_{3}$ was overwritten by a climatology, so the changes discussed here are purely tropospheric. The calculations include the radiative effects of clouds. Comparing instantaneous shortwave and long-wave radiative fluxes at the tropopause between scenarios yields $\mathrm{O}_{3}$ radiative forcings (see Stevenson et al. (1998) for more details on the method). In order to make the $\mathrm{O}_{3}$ forcings directly comparable to other forcings, stratospheric temperatures, which respond on timescales of a month or so to radiative perturbations, need to be adjusted until there is no change in stratospheric heating rates, the socalled "fixed dynamical heating" approximation. Stevenson 
(a) S4s-S4w Ensemble Mean $17.4 \mathrm{~mW} / \mathrm{m} 2$

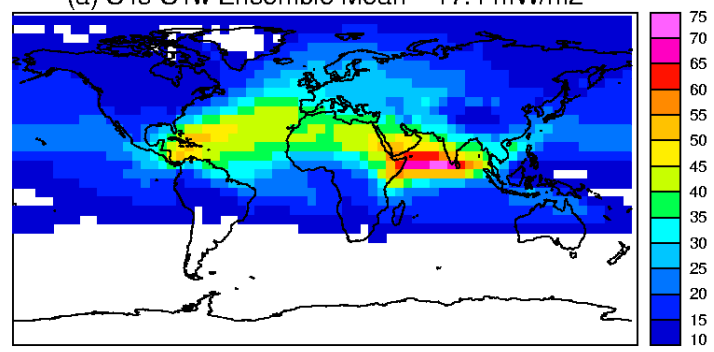

(b) S4s-S4w Ensemble SD $2.9 \mathrm{~mW} / \mathrm{m} 2$

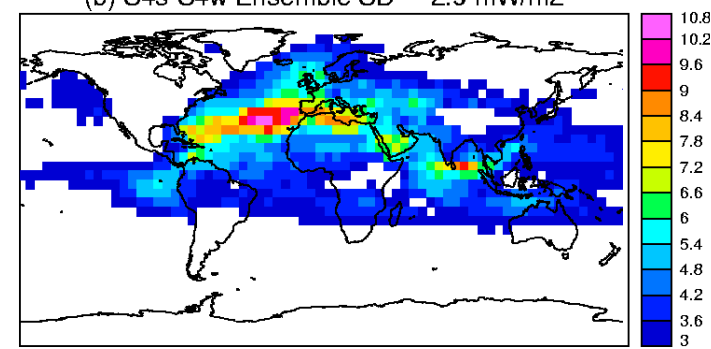

Fig. 12. Ensemble mean for instantaneous tropospheric $\mathrm{O}_{3}$ forcing (a) plus standard deviations (b) in $\mathrm{mW} / \mathrm{m}^{2}$.

et al. (1998) found that this relaxation of stratospheric temperatures resulted in a $22 \%$ reduction in the $\mathrm{O}_{3}$ forcing compared to the instantaneous value and we apply this as a globally constant correction. Figure 12a shows maps of multimodel ensemble mean annual mean instantaneous $\mathrm{O}_{3}$ radiative forcings for the 2030 high emissions case (S4s) relative to the scenario without ships (S4w). Similar distributions were found for the other scenarios. The peak forcing occurs over the Indian Ocean, the site of the largest column $\mathrm{O}_{3}$ changes (Fig. 8), but also a region with relatively high surface temperatures, and a high, cold tropopause. A secondary peak occurs over the Caribbean for similar reasons. Further north over the Atlantic the forcing is less, despite a significant $\mathrm{O}_{3}$ change, reflecting the smaller surface-to-tropopause temperature contrast and increasing cloudiness.

Figure $12 \mathrm{~b}$ shows the inter-model standard deviation, which is typically $15-25 \%$. The ensemble mean forcings and standard deviations for the three cases (S1-S1w, S4-S4w and S4s-S4w), applying a $22 \%$ reduction to account for stratospheric temperature adjustment, are $9.8 \pm 2.0,7.9 \pm 1.4$ and $13.6 \pm 2.3 \mathrm{~mW} / \mathrm{m}^{2}$, respectively. The influence of ship emissions on the $\mathrm{O}_{3}$ forcing slightly reduces as the background $\mathrm{O}_{3}$ levels rise, but the relationship between ship $\mathrm{NO}_{\mathrm{x}}$ emissions and resultant $\mathrm{O}_{3}$ forcing is close to linear. Comparing with the total $\mathrm{O}_{3}$ forcing between 2000 and 2030, as discussed in Stevenson et al. (2006), the contribution from ships in the $\mathrm{S} 4 \mathrm{~s}$ case to the global projected tropospheric $\mathrm{O}_{3}$ forcing is $4 \%$.

Ship $\mathrm{NO}_{\mathrm{x}}$ emissions also affect the radiatively active gas methane, by increasing $\mathrm{OH}$ and reducing the methane lifetime. Five models (CHASER-CTM, FRSGC/UCI, LMDzINCA, STOCHEM-HadAM3 and TM4) provided methane destruction fluxes for each scenario, and these were used to calculate whole atmosphere $\mathrm{CH}_{4}$ lifetimes, as described in Stevenson et al. (2006). For four of the five models, changes in lifetime between scenarios were very consistent (within $4 \%$ of each other), but STOCHEM-HadAM3 was nearly twice as sensitive, and is thus considered an outlier. Here we use ensemble mean results from the four models to assess ship impacts on $\mathrm{CH}_{4}$ lifetime. For present-day, ship $\mathrm{NO}_{\mathrm{x}}$ shortens the $\mathrm{CH}_{4}$ lifetime by 0.13 yr $(1.56 \pm 0.05 \%)$ (S1-
$\mathrm{S} 1 \mathrm{w})$; in 2030 the same ship $\mathrm{NO}_{\mathrm{x}}$ perturbation reduces the lifetime by $0.10 \mathrm{yr}(1.14 \pm 0.02 \%)$ (S4-S4w), again illustrating the slightly lower sensitivity when background levels are higher. Following the A2/CGS the methane lifetime is reduced by an additional $0.07 \mathrm{yr}(0.77 \pm 0.02 \%)$ in 2030 (S4s$\mathrm{S} 4)$. Ship $\mathrm{NO}_{\mathrm{x}}$ therefore introduces a negative radiative forcing by reducing the build-up of methane. We make a firstorder estimate of the methane radiative forcing by linearly scaling the methane lifetime changes, assuming a feedback factor of 1.4 (IPCC, 2001) to infer a change in methane mixing ratio, and then calculate global mean forcing using the value of $0.37 \mathrm{~W} / \mathrm{m}^{2} \mathrm{ppb}^{-1}$ for a globally uniform methane change (Schimel et al., 1996). Estimated methane forcings are given in Table 3 .

The various contributions to the radiative forcing from shipping also include radiative forcing due to $\mathrm{CO}_{2}$ and sulphate changes. The corresponding radiative forcing of $\mathrm{CO}_{2}$ is estimated from the fraction of the ship emission totals in the year $2000(136.7 \mathrm{Tg}(\mathrm{C}) / \mathrm{yr}$, Endresen et al. (2003)) to the total annual $\mathrm{CO}_{2}$ emissions in $2000(7970 \mathrm{Tg}(\mathrm{C}) / \mathrm{yr}$, IPCC (2001), scenario A2). This fraction (1.7\%) is used to scale the $\mathrm{RF}$ resulting from all $\mathrm{CO}_{2}$ sources $\left(1.51 \mathrm{~W} / \mathrm{m}^{2}\right.$, IPCC (2001), scenario A2, ISAM reference case) linearly, resulting in a RF of $26 \mathrm{~mW} / \mathrm{m}^{2}$ due to shipping. The same approach is used to estimate $\mathrm{CO}_{2} \mathrm{RF}$ for the year 2030, with annual emissions of $14,720 \mathrm{Tg}(\mathrm{C}) / \mathrm{yr}$ for all sources (IPCC (2001), scenario A2) and a total $\mathrm{CO}_{2} \mathrm{RF}$ of $2.59 \mathrm{~W} / \mathrm{m}^{2}$ (IPCC (2001), scenario A2, ISAM reference case). The emissions from shipping are assumed to increase at an annual rate of $2.2 \%$ since 2000 , resulting in $262.6 \mathrm{Tg}(\mathrm{C}) / \mathrm{yr}$ in 2030 . For the simulation $\mathrm{S} 4$, shipping contributes with $0.9 \%$ to the total annual $\mathrm{CO}_{2}$ emissions, for $\mathrm{S} 4 \mathrm{~s}$ with $1.8 \%$. This results in $\mathrm{CO}_{2}$ $\mathrm{RF}$ of about $24 \mathrm{~mW} / \mathrm{m}^{2}(\mathrm{~S} 4-\mathrm{S} 4 \mathrm{w})$ and $46 \mathrm{~mW} / \mathrm{m}^{2}(\mathrm{~S} 4 \mathrm{~s}-\mathrm{S} 4 \mathrm{w})$ due to shipping in 2030. However, since $\mathrm{CO}_{2}$ has a long average lifetime, the time integral of ship emissions would be needed to estimate a more accurate number for RF.

Direct sulphate forcings are calculated from the change in total $\mathrm{SO}_{4}$ burdens due to shipping. The relative change of the $\mathrm{SO}_{4}$ burdens is used to scale the total direct radiative forcing of sulphate particles given by IPCC (2001) (scenario A2) of $-0.4 \mathrm{~W} / \mathrm{m}^{2}$ for the year 2000 and $-0.65 \mathrm{~W} / \mathrm{m}^{2}$ for 
the year 2030. The relative contribution of shipping to the total sulphate burdens is about 3.6\% (S1-S1w), 2.0\% (S4$\mathrm{S} 4 \mathrm{w}$ ), and $4.0 \%$ (S4s-S4w). This results in a RF of -14 $\mathrm{mW} / \mathrm{m}^{2}$ (2000, S1-S1w), $-13 \mathrm{~mW} / \mathrm{m}^{2}$ (2030, S4-S4w), and $-26 \mathrm{~mW} / \mathrm{m}^{2}$ (2030, S4s-S4w). It should be noted that the sulphate RFs are only rough estimates, as it is expected that $\mathrm{SO}_{4}$ forcings show a significant variability with emission site and cloud cover, which is not accounted for in this estimate.

RFs from shipping $\mathrm{O}_{3}, \mathrm{CH}_{4}$ and $\mathrm{CO}_{2}$ as well as the direct sulphate forcings for the different scenarios are summarized in Table 3. Contributions to the RF resulting from the indirect aerosol effect (Capaldo et al., 1999) are not included, but are expected to be negative and larger in magnitude than the direct sulphate forcings estimated here.

\section{Discussion}

In the previous section, impacts of $\mathrm{NO}_{\mathrm{x}}$ and $\mathrm{SO}_{2}$ ship emissions on $\mathrm{O}_{3}$ and sulphate distributions have been presented for present-day and 2030 conditions under the same meteorological conditions. In general, the results derived from the ensemble mean comprising ten atmospheric chemistry models agree with previous studies based on single models (Lawrence and Crutzen, 1999; Kasibhatla et al., 2000; Davis et al., 2001; Endresen et al. 2003; Derwent et al., 2005). In this section we discuss the main uncertainties that could impact on results presented in Sect. 3 (Sect. 4.1) and how the results might change in the context of other emission scenarios (Sect. 4.2).

\subsection{Uncertainties}

\subsubsection{Uncertainties in ship emission inventories}

Uncertainties in the emission inventory include uncertainties in the vessel traffic densities and the emission totals. Several emission inventories for shipping based on energy statistics have been published in recent years resulting in a total fuel consumption below or around $160 \mathrm{Mt}$ per year (e.g. Corbett and Fischbeck, 1997; Corbett et al., 1999; Olivier et al., 2001; Endresen et al., 2003). However, recent studies which used an activity-based approach and statistical information of the total fleet greater than 100 GT including the larger military vessels and auxiliary engines (Lloyd's, 2002) suggest a fuel consumption of $289 \mathrm{Mt} / \mathrm{yr}$ (Corbett and Köhler, 2003) or $280 \mathrm{Mt} / \mathrm{yr}$ (Eyring et al. 2005a) for the year 2001. Ideally, the fuel consumption calculated from energy statistics and with an activity-based approach would be the same, but there is an ongoing discussion on the baseline value for the 2000 fuel consumption (Endresen et al., 2004; Corbett and Köhler, 2004; Eyring et al., 2005a). The emission totals for $\mathrm{NO}_{\mathrm{x}}$ used in this study are around a factor of two lower than those calculated from activity-based approaches.

Vessel traffic densities in the inventory used here are based on EDGAR 3.2 (Olivier et al., 2001). Compared to other data sets such as the Comprehensive Ocean-Atmosphere Data Set (COADS, see http://www.wmo.ch/web/www/ois/ois-home. $\mathrm{htm}$ ) or the Automated Mutual-assistance Vessel Rescue system (AMVER; Endresen et al., 2003), shipping routes are probably too narrow in this inventory. As pointed out by Lawrence and Crutzen (1999) this could lead to an underestimation of $\mathrm{O}_{3}$ production, as photochemical production is more efficient at lower $\mathrm{NO}_{\mathrm{x}}$ concentrations (Liu et al., 1987). However, the emissions are instantaneously diluted into the large model grid boxes (see Table 1) which partly compensates this effect. Over the Baltic emissions in the EDGAR3.2 inventory are higher than in the COADS and AMVER data sets, and over the Mediterranean they are smaller. Note that significant differences between the COADS and AMVER data sets have also been reported (Endresen et al., 2003), as only small subsets of the world-merchant fleet find input into these data bases.

Assuming that changes in $\mathrm{O}_{3}$ burden scale linearly with increasing $\mathrm{NO}_{\mathrm{x}}$ emissions (see Sect. 3.3.2), we conclude that the uncertainty arising from $\mathrm{NO}_{\mathrm{x}}$ emission totals in the inventory itself could lead to an underestimation of up to $100 \%$ in the simulated $\mathrm{O}_{3}$ response. We also conclude that due to the inventory used, the process of titration might be overestimated over the Baltic Sea and the impact of ship emissions over the Mediterranean might be underestimated. In addition, the use of a yearly average ship emission inventory is a simplification and e.g. overestimates the impact of ship emissions over the partly frozen Baltic Sea in winter time.

The uncertainties in emission inventories discussed above apply also for the future scenarios. In the future, the global distribution of vessel traffic might change. For example, while international trade in north-south direction and within the Southern Hemisphere is likely increasing, the east-west trade on the long-term might reach a level of saturation and hence reduced growth (Eyring et al., 2005b). However, changes in vessel traffic densities are likely to have only small effects on the global scale, though they could regionally be important. For example, with sea ice expected to recede in the Arctic during the 21 st century as a result of projected climate warming, Granier et al. (2006) showed that the opening of new shipping routes in the Arctic could lead to an important increase in $\mathrm{O}_{3}$ levels in this remote region.

\subsubsection{The impact of VOC and $\mathrm{CO}$ emissions from ships}

We applied one model (MATCH-MPIC) to assess the impact of VOC and CO emissions from ships on tropospheric $\mathrm{O}_{3}$ and $\mathrm{NO}_{\mathrm{x}}$ burdens. These sensitivity simulations with VOC and CO emissions from ships included $(1.2 \mathrm{Tg}(\mathrm{CO}) / \mathrm{yr}$ and $2.03 \mathrm{Tg}(\mathrm{VOCs}) / \mathrm{yr}$ in 2000 from Endresen et al. (2003); $2.15 \mathrm{Tg}(\mathrm{CO}) / \mathrm{yr}$ and $3.89 \mathrm{Tg}(\mathrm{VOCs}) / \mathrm{yr}$ in 2030 under CGS) are displayed in Figs. 9 and 10 (MATCH-MPIC/VOC) and show only small differences compared to the MATCH-MPIC reference simulations. The differences are most apparent over the Baltic where $\mathrm{NO}_{\mathrm{x}}$ are dominated by high emissions 
from land in the $5^{\circ} \times 5^{\circ}$ model grid boxes. On the global scale as well as in the Pacific and Indian Ocean the differences are small, and even in the Baltic the difference between the sensitivity and reference simulations in the MATCH-MPIC model are much smaller than the inter-model differences. We therefore conclude that the neglect of ship CO and VOC emissions in the reference simulations does not change the main conclusions of this paper. This can be understood, because total $\mathrm{CO}$ emissions from ships are small and VOC emissions are not expected to play a significant role over the remote ocean: (1) In general, CO emission is the result of incomplete combustion. Since large-bore diesel engines operate at high air excess ratios and high combustion temperatures, total CO emissions from the fleet above 100 GT are small and much lower than from other internal combustion engines (see Eyring et al., 2005a). (2) Past global modelling studies (e.g. Stevenson et al., 1998; Stevenson et al., 2006) have found that the troposphere is mainly $\mathrm{NO}_{\mathrm{x}}$-limited with respect to $\mathrm{O}_{3}$ production, as is to be expected since the vast majority of it is quite "remote" from $\mathrm{NO}_{\mathrm{x}}$ emissions. This is particularly true for oceanic regions. VOC-limited $\mathrm{O}_{3}$ production regions are typically limited to highly polluted, urban areas. With the exception of the Baltic Sea these rarely occur, even in the most congested shipping lanes, at least when they are represented in the global model grid-boxes of $5^{\circ}$ longitude $\times 5^{\circ}$ latitude. Therefore, even though the models describe atmospheric photochemistry in considerable detail, and include multiple non-linear interactions, this doesn't mean one should necessarily expect non-linear relationships in the shipping response. Indeed, the response of the modelled $\mathrm{NO}_{\mathrm{x}}$ and $\mathrm{O}_{3}$ burdens to varying the magnitude of ship $\mathrm{NO}_{\mathrm{x}}$ emissions is basically linear whether or not VOC emissions from ships are included (Fig. 9), but as discussed in Sect. 3.3.2 small saturation affects are simulated. These findings are in agreement with results from Endresen et al. (2003) who also showed that the effects of VOC emissions from ships on present-day $\mathrm{O}_{3}$ are very small.

\subsubsection{The role of plume dispersion}

Many physical and chemical processes in the atmosphere occur on spatial and temporal scales that cannot be resolved in current global numerical models, which have typical resolutions of a few hundred kilometres. One major open issue is the evolution and chemical transformation of trace gases and particulate matter emitted from individual point sources such as e.g. a single ship during the dispersion into the large scales of a grid cell of a global model. Emission totals are based on specific fuel-oil consumption rates and emission indices measured at the manufacturers' engine test beds (e.g. Eyring et al., 2005a). The emission totals are distributed over the globe with the help of vessel traffic densities derived in various ways and are instantaneously spread onto large inventory grid boxes, usually $1^{\circ}$ longitude $\times 1^{\circ}$ degree latitude, without accounting for chemical dispersion on the sub-grid scale.
Those inventories are used as inputs in emission databases such as EDGAR (Olivier et al., 2001) and global modelling studies. The horizontal resolution in the global models used in this study all have even larger grid sizes of a few hundred kilometres (see Table 1). Therefore, emissions from ships are further instantaneously distributed within the large grid boxes. However, several studies have pointed to the importance of chemical conversion in the near field of ships (Kasibhatla et al., 2000; Davis et al., 2001; Song et al., 2003; von Glasow et al., 2003; Chen et al., 2005). Uncertainties in the modelled $\mathrm{O}_{3}$ changes arising from the neglect of plume chemistry are hard to quantify, in particular because the studies cited above are all based on certain meteorological situations, amount of emissions released by the ship, and daytime. However, the studies all agree in this respect that the lifetime of $\mathrm{NO}_{\mathrm{x}}$ is significantly reduced in the plumes, corresponding to high in-plume $\mathrm{NO}_{\mathrm{x}}$ destruction. Chen et al. (2005) used a box model and found that more than $80 \%$ of the $\mathrm{NO}_{\mathrm{x}}$ loss is due to the reaction of $\mathrm{NO}_{2}$ with $\mathrm{OH}$ and the rest due to PAN formation. As parameterisations that account for these subgrid scale processes are not yet available, the model simulations have been run without accounting for sub-grid plume chemistry, but with a relatively low total emission estimate (Sect. 4.1.1).

\subsubsection{Uncertainties due to different model approaches}

Uncertainties in different model approaches presented here and discussed in Sect. 3.2 arise from differences in the main characteristics in the models (see Sect. 2.1). The advantage of this study compared to all previous assessments on ship emissions is that an ensemble of ten models has been used, which makes the results more robust, because the models have performed the same experiments with different treatments of chemical and dynamical processes. In summary, the differences in the simulated contributions from shipping to $\mathrm{O}_{3}, \mathrm{NO}_{2}$, sulphate and $\mathrm{RF}$ are smaller than $20 \%$, as revealed by the intermodel standard deviations.

\subsection{Results in the context of other emission scenarios}

Up to now we have only quantified the impact of ship emissions in 2030 under the assumption that all other emissions vary as projected in the A2 scenario. The A2 scenario is a rather pessimistic scenario, which describes a very heterogeneous world with high population growth. Economic development is primarily regionally oriented and per capita economic growth and technological changes are more fragmented and slower than in other IPCC SRES storylines. $\mathrm{NO}_{\mathrm{x}}$ emissions in $\mathrm{A} 2$ increase to $179 \mathrm{Tg}\left(\mathrm{NO}_{2}\right) \mathrm{yr}^{-1}$ in 2030 . However, if ground based emissions grow less rapidly than un$\operatorname{der} \mathrm{A} 2$, the relative contribution of ship emissions will become more important. The 'Current Legislation Scenario (CLE)' scenario takes into account the current perspectives of individual countries on future economic development and 

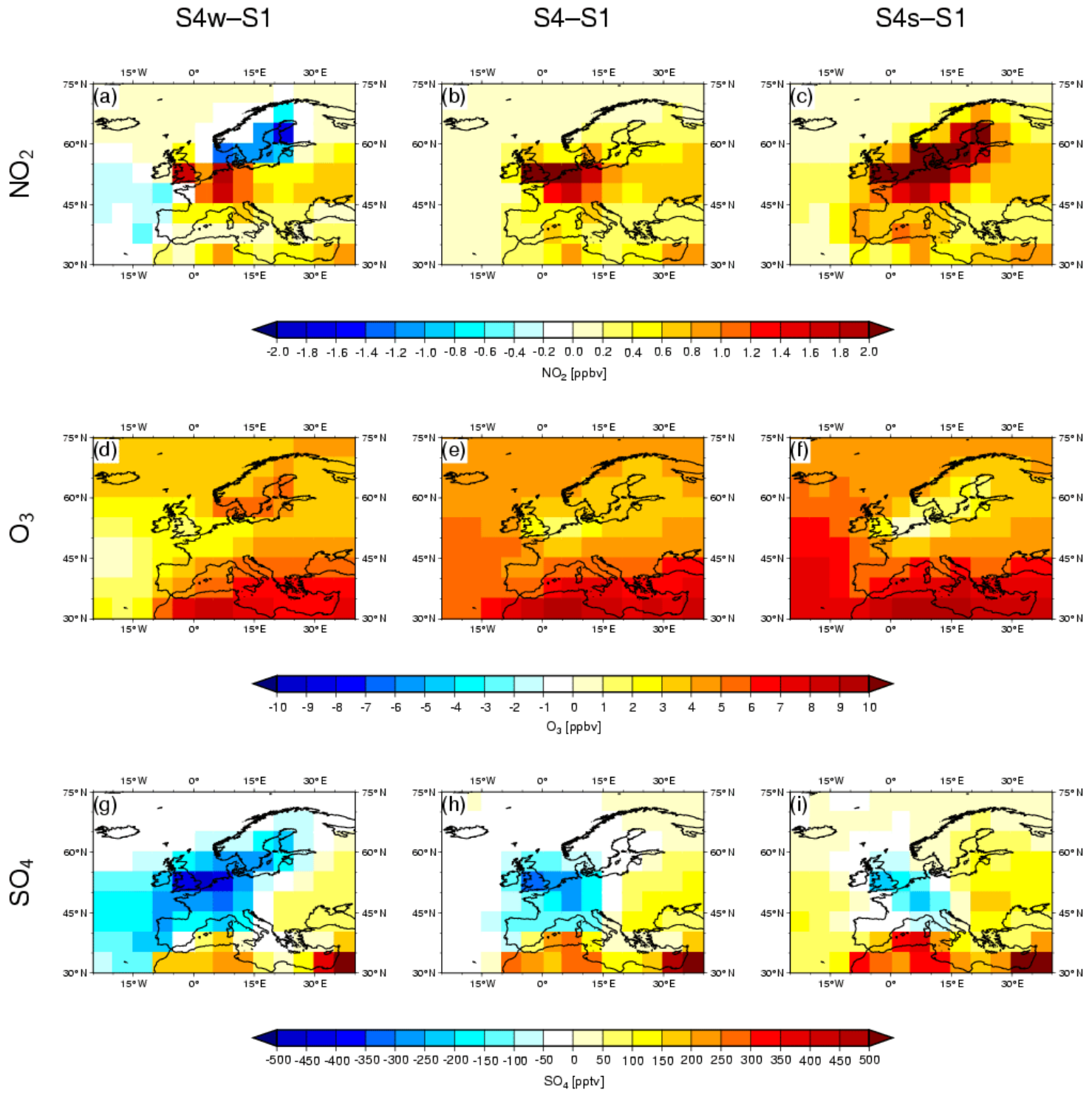

Fig. 13. Changes 2030-2000 over Europe under the IPCC SRES A2 scenario with different assumptions for ship emissions. Left: Changes in a world without ship emissions in 2030; Middle: Changes in a world with ship emissions remaining at 2000 levels; Right: Changes under the "Constant Growth Scenario".

anticipated effects of presently decided emission control legislation in the individual countries and the "Maximum technically Feasible Reduction" (MFR) scenario considers the scope for emission reductions offered by full implementation of the presently available emission control technologies, while maintaining the projected levels of anthropogenic activities. A detailed description of the two scenarios can be found in Dentener et al. (2005). Compared to today's anthropogenic $\mathrm{NO}_{\mathrm{x}}$ emissions (91.3 $\mathrm{Tg}\left(\mathrm{NO}_{2}\right) \mathrm{yr}^{-1}$ in $\mathrm{S} 1$; not including biomass burning), $\mathrm{NO}_{\mathrm{x}}$ emissions in the CLE scenario increase to $108 \mathrm{Tg}\left(\mathrm{NO}_{2}\right) \mathrm{yr}^{-1}$ and decrease to 43.0 $\operatorname{Tg}\left(\mathrm{NO}_{2}\right) \mathrm{yr}^{-1}$ in the MFR scenario in 2030 (Stevenson et al., 2006, Table 3). Differences in tropospheric $\mathrm{O}_{3}$ burden be- tween 2030 and 2000 for the three scenarios A2, CLE, and MFR have been calculated from an ensemble of 26 models in Stevenson et al. (2006), their Table 6. The simulated inter-scenario ensemble mean changes in $\mathrm{O}_{3}$ burdens between 2030 and 2000 resulted in $53 \pm 10 \mathrm{Tg}\left(\mathrm{O}_{3}\right)$ in the A2 scenario with ship emissions remaining at 2000 levels (S4$\mathrm{S} 1), 20 \pm 4 \operatorname{Tg}\left(\mathrm{O}_{3}\right)$ in the CLE scenario, and $-16 \pm 4 \mathrm{Tg}\left(\mathrm{O}_{3}\right)$ in the MFR scenario. If we add on the $1.75 \operatorname{Tg}\left(\mathrm{O}_{3}\right)$ increase in $\mathrm{O}_{3}$ burdens due to ship emission increase under the A2/CGS calculated in this study (see Fig. 9) to the difference in $\mathrm{O}_{3}$ burden between the $\mathrm{S} 4$ and the $\mathrm{S} 1$ simulation from Stevenson et al. (2006), the global mean relative contribution from shipping is around 3\% under the A2 scenario. 
However, under the CLE scenario the relative contribution of ships to $\mathrm{O}_{3}$ burden trends until 2030 increases to around 9\%. If land-based emissions fall, as under the MFR scenario, but ship emissions continue to grow, they will significantly counteract the benefits derived from the land-based emissions reductions.

As an example how increases in ship emissions might impact on future trends, Fig. 13 shows differences in nearsurface $\mathrm{NO}_{2}, \mathrm{O}_{3}$ and sulphate between the $2030 \mathrm{~A} 2$ scenario and 2000 over Europe if ship emissions are zero in 2030 (S4w-S1; left column), remain constant at 2000 levels (S4$\mathrm{S} 1$; middle column), or increase with a constant growth rate of $2.2 \% / \mathrm{yr}$ (S4s-S1; right column).

If $\mathrm{NO}_{\mathrm{x}}$ emissions from shipping fall to zero in 2030, a decrease in near-surface $\mathrm{NO}_{2}$ concentrations between 2030 and 2000 of up to 2 ppbv over Scandinavia and 0.4 ppbv over the Atlantic can be reached (a reduction of over $50 \%$ ), whereas central Europe is dominated by increases due to the rise in land $\mathrm{NO}_{\mathrm{x}}$ emissions (Fig. 13a). On the other hand, with constant or increasing emissions from shipping (Fig. 13b,c) near-surface $\mathrm{NO}_{2}$ levels are enhanced over the continent by up to $2 \mathrm{ppbv}$ ( $>50 \%$ ), in particular over the coastal regions of the North Sea and the Baltic Sea as well as over the southern part of Great Britain. Only small differences in $\mathrm{O}_{3}$ are simulated under the three different ship emission scenarios (Figs. 13d-f). In a world without ship $\mathrm{NO}_{\mathrm{x}}$ emissions in 2030, the positive trend in near-surface $\mathrm{O}_{3}$ will be reduced over most of Europe (Fig. 13d), whereas it will be enhanced in the A2/CGS (Fig. 13f).

The strongest impact of ship emissions to the trends up to 2030 is simulated in the sulphate distributions. A significant decrease in sulphate is simulated in a world without ship emissions in 2030 (Fig. 13g). If ship emissions however remain at today's levels, this negative trend over Central Europe and the United Kingdom is reduced and even changes sign over large areas of the Atlantic and over Scandinavia under the A2/CGS (Fig. 13i). Thus, increasing emissions from shipping would significantly counteract the benefits derived from reducing $\mathrm{SO}_{2}$ emissions from all other anthropogenic sources under the A2 scenario over the continents in Europe.

\section{Summary and Conclusions}

In this study we have used an ensemble of ten state-of-theart global atmospheric chemistry models to assess the impact of $\mathrm{NO}_{\mathrm{x}}$ emissions from international shipping on $\mathrm{O}_{3}$ for present-day conditions (year 2000). This multi-model approach accounts for intermodel differences and therefore makes the results more robust compared to previous studies. In addition this study for the first time quantifies the potential impact of ship emissions in the future (year 2030). A subset of four models included the tropospheric sulphur cycle. The ensemble mean of these four models has been applied to investigate the changes in sulphate distributions due to $\mathrm{SO}_{2}$ emissions from international shipping for present-day conditions and in 2030.

For present-day conditions we find the most pronounced changes in annual mean tropospheric $\mathrm{NO}_{2}$ and $\mathrm{SO}_{4}$ columns over the Baltic and the North Sea, and also though smaller over the Atlantic, Gulf of Mexico, and along the main shipping lane from Europe to Asia. Maximum near-surface $\mathrm{O}_{3}$ changes due to $\mathrm{NO}_{\mathrm{x}}$ ship emissions are simulated over the North Atlantic in July $(\sim 12$ ppbv) in agreement with previously reported results (Lawrence and Crutzen, 1999; Endresen et al., 2003). However, in contrast to Endresen et al. (2003), a decrease in $\mathrm{O}_{3}$ in winter is found over large areas in Europe ( $\sim 3$ ppbv) due to titration, which could be related to differences in the emission inventories. Overall $\mathrm{NO}_{\mathrm{x}}$ emissions most effectively produce $\mathrm{O}_{3}$ over the remote ocean, where background $\mathrm{NO}_{\mathrm{x}}$ levels are small.

The two 2030 scenarios both specify emissions following the IPCC SRES A2 scenario (IPCC, 2000). The first future scenario assumes that ship emissions remain constant at 2000 levels and under this scenario a slightly smaller response in $\mathrm{O}_{3}$ and sulphate changes due to shipping is found compared to the present-day contribution from shipping. This indicates that higher background levels tend to slightly reduce the perturbation from ships. The second emission scenario addresses the question of how $\mathrm{NO}_{\mathrm{x}}$ and $\mathrm{SO}_{2}$ emissions from international shipping might influence atmospheric chemistry in the next three decades if these emissions grow unabated and one assumes a constant annual growth rate of 2.2\% between 2000 and 2030 ("Constant Growth Scenario" (CGS)). The models show future increases in $\mathrm{NO}_{\mathrm{x}}$ and $\mathrm{O}_{3}$ burden which scale almost linearly with increases in $\mathrm{NO}_{\mathrm{x}}$ emission totals under the same background conditions. Therefore, there is evidence that the ship $\mathrm{NO}_{\mathrm{x}}$ effect is only weakly subject to saturation in its current magnitude range, and that saturation cannot be expected to help mitigate the effects of near-future increases. In other words a doubling of $\mathrm{NO}_{\mathrm{x}}$ emissions from ships in the future might lead to a doubling in atmospheric $\mathrm{O}_{3}$ burdens due to ship emissions. In addition, increasing emissions from shipping would significantly counteract the benefits derived from reducing $\mathrm{SO}_{2}$ emissions from all other anthropogenic sources under the A2 scenario over the continents, for example in Europe. Under A2/CGS shipping globally contributes with $3 \%$ to increases in $\mathrm{O}_{3}$ burden until 2030 and with $4.5 \%$ to increases in sulphate. The results discussed above are calculated under the assumption that all other emissions follow the A2 scenario broadly representing a pessimistic future situation. However, if future ground based emissions follow a more stringent scenario, the relative importance of ship emissions becomes larger.

Tropospheric $\mathrm{O}_{3}$ forcings due to ships of $9.8 \mathrm{~mW} / \mathrm{m}^{2}$ in 2000 and $13.6 \mathrm{~mW} / \mathrm{m}^{2}$ in 2030 are simulated by the ensemble mean, with standard deviations of $10-15 \%$. Compared to aviation $\left(\sim 20 \mathrm{~mW} / \mathrm{m}^{2}\right.$; Sausen et al., 2005) tropospheric $\mathrm{O}_{3}$ forcings from shipping are of the same order in 2000, despite the much higher $\mathrm{NO}_{\mathrm{x}}$ emissions from ships (Eyring et 
al., 2005a). This can be understood because peak changes in $\mathrm{O}_{3}$ due to shipping occur close to the surface, whereas changes in $\mathrm{O}_{3}$ due to aviation peak in the upper troposphere (Grewe et al., 2002). The net radiative forcing is most sensitive to $\mathrm{NO}_{\mathrm{x}}$ emissions at altitudes of about $8-12 \mathrm{~km}$ because of longer $\mathrm{NO}_{\mathrm{x}}$ and $\mathrm{O}_{3}$ lifetimes, and colder temperatures compared to the surface (Lacis et al., 1990; Brasseur et al., 1998). Ship $\mathrm{NO}_{\mathrm{x}}$ reduces the $\mathrm{CH}_{4}$ lifetime by $0.13 \mathrm{yr}$ in 2000 and by up to $0.17 \mathrm{yr}$ in 2030 , introducing a negative radiative forcing of about $-14 \mathrm{~mW} / \mathrm{m}^{2}$ in 2000 and $-21 \mathrm{~mW} / \mathrm{m}^{2}$ in 2030. A rough estimate of $\mathrm{RF}$ from shipping $\mathrm{CO}_{2}$ suggests $26 \mathrm{~mW} / \mathrm{m}^{2}$ in 2000 compared to $23 \mathrm{~mW} / \mathrm{m}^{2}$ from aviation $\mathrm{CO}_{2}$. The direct effect from $\mathrm{SO}_{2}$ ship emissions is approximately $-14 \mathrm{~mW} / \mathrm{m}^{2}$ in 2000 and decreases to a more negative value of $-26 \mathrm{~mW} / \mathrm{m}^{2}$ in 2030 under A2/CGS.

The recent rapid rise in ship emissions may have generated $\mathrm{O}_{3}$ trends that have hitherto been attributed to increases in hemispheric background, and related to North American or Asian anthropogenic emissions, or to changes in forest fire activities (e.g. observations at Mace Head, Simmonds et al., 2005). For example, Lelieveld et al. (2004) report significant surface $\mathrm{O}_{3}$ trends over the Atlantic Ocean, although not particularly over the North Atlantic, where ships appear to have their largest impact in our study. The large rise in ship emissions and the associated increase in $\mathrm{O}_{3}$ may be compromising measures to reduce $\mathrm{O}_{3}$ in some regions, e.g. Europe and potentially elsewhere (India, western North America). Of the estimated $0.35 \mathrm{~W} / \mathrm{m}^{2}$ radiative forcing since 1750 due to increases in tropospheric $\mathrm{O}_{3}$, our results indicate that about $4 \%$ of this is due to ship $\mathrm{NO}_{\mathrm{x}}$ emissions.

This study has also investigated the range of results given by the individual models compared to other uncertainties. Uncertainties in the simulated $\mathrm{O}_{3}$ contributions from ships for the different model approaches revealed by the intermodel standard deviations are found to be significantly smaller than estimated uncertainties stemming from the ship emission inventory, mainly the ship emission totals, the distribution of the emissions over the globe, and the neglect of ship plume dispersion. The relatively small intermodel variance lends to confidence to our use of current models to study the effects of shipping, while highlighting the urgent need to quantify the uncertainties that may be present or to the plume nature of shipping emissions.

The results of the ship induced $\mathrm{O}_{3}, \mathrm{NO}_{\mathrm{x}}$ and $\mathrm{SO}_{2}$ changes discussed above are derived from one particular ship emission inventory. The main goal for future work is to reduce uncertainties in the emissions totals and to further improve vessel traffic densities as well as to develop sophisticated parameterisations of unresolved plume processes for the use in global models.

An intercomparison of the model results with observations over the Northern Hemisphere $\left(25^{\circ}-60^{\circ} \mathrm{N}\right)$ oceanic regions in the lower troposphere showed that the models are capable to reproduce $\mathrm{O}_{3}$ and $\mathrm{NO}_{x}$ reasonably well, whereas $\mathrm{SO}_{2}$ in the marine boundary layer is significantly underestimated.
However, evaluation of the models' response to ship emissions is still at a preliminary stage and is currently limited by the coarse spatial resolution of the models, the uncertainty in the measurements, the lack of sufficient in situ measurements over the ocean, and the difficulty to separate ship emissions from other even stronger emission sources close to land. Additional in situ measurements inside single ship plumes, but also in the corridor of the shipping lanes are needed and the set up of a measurement network onboard ships similar to MOZAIC (Measurements of OZone and water vapour by inservice AIrbus airCraft; Marenco et al., 1998) or CARIBIC (Civil Aircraft for Global Measurement of Trace Gases and Aerosols in the Tropopause Region; Brenninkmeijer et al., 1999) onboard civil aircrafts would be desirable. Unambiguous detection of ship emissions in satellite data is currently only available for the region of the Red Sea and the Indian Ocean (Beirle et al., 2004; Richter et al., 2004), where shipping routes are close to the coastal area. Reduction in measurement uncertainties through use of long-term averages and data from more instruments (e.g. OMI and GOME-2) combined with better constraints on land-based sources and higher spatial resolution in the models should facilitate such an intercomparison in the future.

Acknowledgements. Co-ordination of this study was supported by the European Union project ACCENT (Atmospheric Composition Change: the European NeTwork of excellence. http://www.accent-network.org). The study has also been supported by the Helmholtz-University Young Investigators Group SeaKLIM, which is funded by the Helmholtz Association of German Research Centres and the German Aerospace Center (DLR). We thank L. Emmons and colleagues as well as NASA and partners for making their data composites of airborne observations freely available on the internet and easily accessible in a format that is suitable for global model evaluation. We also thank the two anonymous reviewers for their comments on the manuscript.

Edited by: R. von Glasow

\section{References}

Beirle, S., Platt, U., von Glasow, R., Wenig, M., and Wagner T.: Estimate of nitrogen oxide emissions from shipping by satellite remote sensing, Geophys. Res. Lett., 31, L18102, doi:10.1029/2004GL020312, 2004.

Bey, I., Jacob, D. J., Yantosca, R. M., et al.: Global modelling of tropospheric chemistry with assimilated meteorology: Model description and evaluation, J. Geophys. Res., 106, 23 073-23 095, 2001.

Brasseur, G., Cox, R., Hauglustaine, D. A., Isaksen, I. S. A., Lelieveld, J., Lister, D., Sausen, R., Schumann, U., Wahner, A., and Wiesen, P.: European scientific assessment of the atmospheric effect of aircraft emissions. Atmos. Environ., 32, 23292418, 1998.

Brenninkmeijer, C. A. M., Crutzen, P. J. , Fischer, H., Güsten, H., Hans, W., Heinrich, G., Heintzenberg, J., Hermann, M., Immelmann, T., Kersting, D., Maiss, M., Nolle, M., Pitscheider, A., 
Pohlkamp, H., Scharffe, D., Specht, K. and Wiedensohler, A.: CARIBIC - Civil aircraft for global measurement of trace gases and aerosols in the tropopause region, J. Atmos. Oceanic Technology, 16, 1373-1383, 1999.

Capaldo, K., Corbett, J. J., Kasibhatla, P., Fischbeck, P. S., and Pandis, S. N.: Effects of ship emissions on sulfur cycling and radiative climate forcing over the ocean, Nature, 400, 743-746, 1999.

Chen, G., Huey, L. G., Trainer, M., Nicks, D., Corbett, J., Ryerson, T., Parrish, D., Neuman, J. A., Nowak, J., Tanner, D., Holloway, J., Brock, C., Crawford, J., Olson, J. R., Sullivan, A., Weber, R., Schauffler, S., Donnelly, S., Atlas, E., Roberts, J., Flocke, F., Hubler, G., and Fehsenfeld, F.: An investigation of the chemistry of ship emission plumes during ITCT 2002, J. Geophys. Res., 110, D10S90, doi:10.1029/2004JD005236, 2005.

Collins, W. J, Stevenson, D. S., Johnson, C. E., and Derwent, R. G.: Tropospheric ozone in a global-scale three-dimensional Lagrangian model and its response to $\mathrm{NO}_{\mathrm{x}}$ emission controls, $\mathrm{J}$. Atmos. Chem., 26, 223-274, 1997.

Collins, W. J., Derwent, R. G., Garnier, B., Johnson, C. E., Sanderson, M. G., and Stevenson, D. S.: The effect of stratospheretroposphere exchange on the future tropospheric ozone trend, J. Geophys. Res., 108(D12), 8528, doi:10.1029/2002JD002617, 2003.

Corbett, J. J. and Fischbeck, P.: Emissions from ships, Science, 278(5339), 823-824, 1997.

Corbett, J. J., Fischbeck, P. S., and Pandis, S. N.: Global nitrogen and sulfur inventories for oceangoing ships, J. Geophys. Res., 104(3), 3457-3470, 1999.

Corbett, J. J. and Köhler, H. W.: Updated emissions from ocean shipping, J. Geophys. Res., 108, 4650, doi:10.1029/2003JD003751, 2003.

Corbett, J. J. and Köhler, H. W.: Considering alternative input parameters in an activity-based ship fuel consumption and emissions model: Reply to comment by Øyvind Endresen et al. on "Updated emissions from ocean shipping", J. Geophys. Res., 109, D23303, doi:10.1029/2004JD005030, 2004.

Davis, D. D., Grodzinsky, G., Kasibhatla, P., Crawford, J., Chen, G., Liu, S., Bandy, A., Thornton, D., Guan, H., and Sandholm, S.: Impact of ship emissions on marine boundary layer $\mathrm{NO}_{\mathrm{x}}$ and $\mathrm{SO}_{2}$ distributions over the Pacific Basin, Geophys. Res. Lett., 28, 235-238, 2001.

Dentener, F., Peters, W., Krol, M., van Weele, M., Bergamaschi, P., and Lelieveld, J.: Interannual variability and trend of $\mathrm{CH}_{4}$ lifetime as a measure for OH changes in the 1979-1993 time period, J. Geophys. Res., 108(D15), 4442, doi:10.1029/2002JD002916, 2003.

Dentener, F., Stevenson, D. S., Cofala, J., Mechler, R., Amann, M., Bergamaschi, P., Raes, F., and Derwent, R. G.: The impact of air pollutant and methane emission controls on tropospheric ozone and radiative forcing: CTM calculations for the period 19902030, Atmos. Chem. Phys., 5, 1731-1755, 2005,

http://www.atmos-chem-phys.net/5/1731/2005/.

Dentener, F., Stevenson, D., Ellingsen, K., Van Noije, T., Schultz, M., Amann, M., Atherton, C., Bell, N., Bergmann, D., Bey, I., Bouwman, L., Butler, T., Cofala, J., Collins, W., Doherty, R., Drevet, J., Eickhout, B., Eskes, H., Fiore, A., Gauss, M., Hauglustaine, D., Horowitz, L., Isaksen, I. S. A., Josse, B., Krol, M., Lamarque, J. F., Lawrence, M., Montanaro, V., Mller, J. F., Peuch, V. H., Pitari, G., Pyle, J., Rast, S., Rodriguez, J., Sander- son, M., Savage, N., Shindell, D., Strahan, S., Szopa, S., Sudo, K., Van Dingenen, R., Wild, O., and Zeng, G.: Global Atmospheric Environment for the next generation, Environmental Science and Technology, 40, 3586-3594, 2006 a.

Dentener, F., Drevet, J., Lamarque, J. F., Bey, I., Eickhout, B., Fiore, A., Hauglustaine, D., Horowitz, L. W., Krol, M., Kulshrestha, U. C., Lawrence, M., Galy-Lacaux, C., Rast, S., Shindell, D., Stevenson, D., van Noije, T., Atherton, C., Bell, N., Bergmann, D., Butler, T., Cofala, J., Collins, B., Doherty, R., Ellingsen, K., Galloway, J., Gauss, M., Montanaro, V., Mller, J. F., Pitari, G., Rodriguez, J., Sanderson, M., Solomon, F., Strahan, S., Schultz, M., Sudo, K., Szopa, S., and Wild, O.: Nitrogen and sulphur deposition on regional and global scales: A multi-model evaluation, Global Biogeochem. Cy., 20, GB4003, doi:10.1029/2005GB002672, 2006 b.

Derwent, R. G, Stevenson, D. S., Doherty, R. M., Collins, W. J., Sanderson, M. G., Johnson, C. E., Cofala, J., Mechler, R., Amann, M., and Dentener, F. J.: The contribution from ship emissions to air quality and acid deposition in Europe, Ambio, 34, 54-59, 2005.

Edwards, J. M. and Slingo, A.: Studies with a flexible new radiation code. I: choosing a configuration for a large-scale model, Quart. J. Roy. Meteor. Soc., 122, 689-719, 1996.

Endresen, Ø., Sørgård , E., Sundet, J. K., Dalsøren, S. B., Isaksen, I. S. A., Berglen, T. F., and Gravir, G.: Emission from international sea transportation and environmental impact, J. Geophys. Res. 108, 4560, doi:10.1029/2002JD002898, 2003.

Endresen, Ø., Sørgård, E., Bakke, J., and Isaksen, I.S.A.: Substantiation of a lower estimate for the bunker inventory: Comment on "Updated emissions from ocean shipping" by James J. Corbett and Horst W. Koehler, J. Geophys. Res., 109, D23302, doi:10.1029/2004JD004853, 2004.

Emmons, L. K., Hauglustaine, D. A., Muller, J.-F., Carroll, M. A., Brasseur, G. P., Brunner, D. , Staehelin, J., Thouret, V., and Marenco, A.: Data composites of airborne observations of tropospheric ozone and its precursors, J. Geophys. Res., 105, $20497-$ 20538, 2000.

EPA (Environmental Protection Agency, U.S.A.), SPECIATE 3.2, profiles of total organic compounds and particulate matter, http: //www.epa.gov/ttn/chief/software/speciate/index.html, 2002.

Esler, J. G.: An integrated approach to mixing sensitivities in tropospheric chemistry: A basis for the parameterization of subgridscale emissions for chemistry transport models, J. Geophys. Res., 108(D20), 4632, doi:10.1029/2003JD003627, 2003.

Eyring, V., Köhler, H. W., van Aardenne, J., and Lauer, A.: Emissions from international shipping: 1 . The last 50 years, J. Geophys. Res., 110, D17305, doi:10.1029/2004JD005619, 2005a.

Eyring, V., Köhler, H. W., Lauer, A., and Lemper, B.: Emissions from international shipping: 2. Impact of future technologies on scenarios until 2050, J. Geophys. Res., 110, D17306, doi:10.1029/2004JD005620, 2005b.

Granier, C., Niemeier, U., Jungclaus, J. H., Emmons, L., Hess, P., Lamarque, J.-F., Walters, S., and Brasseur, G. P.: Ozone pollution from future ship traffic in the Arctic northern passages, Geophys. Res. Lett., 33, L13807, doi:10.1029/2006GL026180, 2006.

Grewe, V., Dameris, M., Fichter, C., and Sausen, R.: Impact of aircraft $\mathrm{NO}_{\mathrm{x}}$ emissions. Part 1: Interactively coupled climatechemistry simulations and sensitivities to climate-chemistry 
feedback, lightning and model resolution, Meteorol. Z., 3, 177$186,2002$.

Hauglustaine, D. A., Hourdin, F., Walters, S., Jourdain, L., Filiberti, M.-A., Larmarque, J.-F., and Holland, E.A.: Interactive chemistry in the Laboratoire de Météorologie Dynamique general circulation model : description and background tropospheric chemistry evaluation, J. Geophys. Res., 109, D04314, doi:10.1029/2003JD003957, 2004.

Haywood, J. M., and Shine, K. P.: The effect of anthropogenic sulphate and soot aerosol on the clear sky planetary radiation budget, Geophys. Res. Lett., 22(5): 603-606, 1995.

Isaksen, I. S. A., Zerefos, C. S., Kourtidis, K., Meleti, C., Dalsoren, S. B., Sundet, J. K., Grini, A., Zanis, P., and Balis, D.: Tropospheric ozone changes at unpolluted and semipolluted regions induced by stratospheric ozone changes, J. Geophys. Res., 110 (2), D02302, doi: 10.1029/2004JD004618, 2005.

IMO (International Maritime Organization): IMO Sub-Committee on Bulk Materials, $22^{\text {nd }}$ Session, Agenda Item 7, Ref.code IMO, BCH 22/INF.10, IMO, London, 1992.

IMO (International Maritime Organization): Regulations for the prevention of air pollution from ships and $\mathrm{NO}_{\mathrm{x}}$ technical code, ANNEX VI of MARPOL 73/78, London, 1998.

IPCC (Intergovernmental Panel on Climate Change): Special report on emissions scenarios: a special report of Working Group III of the Intergovernmental Panel on Climate Change, 599 pp., Cambridge University Press, Cambridge, U.K, 2000.

IPCC (Intergovernmental Panel on Climate Change): Climate change 2001: The scientific basis. Contribution of Working Group 1 to the Third Assessment Report, J. T. Houghton, Cambridge University Press, Cambridge, United Kingdom and New York, NY, USA, 2001.

Kasibhatla, P., Levy II, H., Moxim, W. J., Pandis, S. N., Corbett, J. J., Peterson, M. C., Honrath, R. E., Frost, G. J., Knapp, K., Parrish, D. D., and Ryerson, T. B.: Do emissions from ships have a significant impact on concentration of nitrogen oxides in the marine boundary layer?, Geophys. Res. Lett., 27(15), 22292233,2000 .

Labrador, L. J., von Kuhlmann, R., and Lawrence, M. G.: Strong sensitivity of the global mean $\mathrm{OH}$ concentration and the troposphere's oxidizing efficiency to the source of $\mathrm{NO}_{\mathrm{x}}$ from lightning, Geophys. Res. Lett., 31(6), L06102, doi:10.1029/2003GL019229, 2004.

Lacis, A. A., Wuebbles, D. J., and Logan, J. A.: Radiative forcing of climate by changes in the vertical distribution of ozone, J. Geophys. Res., 95, 9971-9981, 1990.

Langner, J. and Rodhe, H.: A global three-dimensional model of the tropospheric sulphur cycle, J. Atmos. Chem., 13, 225-263, 1991.

Lawrence, M. G. and Crutzen, P. J.: Influence of $\mathrm{NO}_{\mathrm{x}}$ emissions from ships on tropospheric photochemistry and climate, Nature, 402, 167-170, 1999.

Lawrence, M. G., Crutzen, P. J., Rasch, P. J., Eaton, B. E., and Mahowald, N. M.: A model for studies of tropospheric photochemistry: Description, global distributions, and evaluation. J. Geophys. Res., 104, 26 245-26 277, 1999.

Lelieveld, J., van Ardenne, J., Fischer, H., de Reus, M., Williams, J., and Winkler, P.: Increasing ozone over the Atlantic Ocean, Science, 304(5676), 1483-1487, 2004.

Lloyd's Maritime Information System (LMIS): The Lloyd's Mar- itime Database [CD-ROM], Lloyd's Register-Fairplay Ltd., London, 2002.

Marenco, A., Thouret, V., Nédélec, P., Smit, H., Helten, M., et al.: Measurement of ozone and water vapor by Airbus in-service aircraft: The MOZAIC airborne program, An overview, J. Geophys. Res., 103(D19), 25 631-25 642, 1998.

Olivier, J. G. J. and Berdowski, J. J. M.: Global emissions sources and sinks, in: The climate system, edited by: J. J. M. Berdowski, R. Guicherit, and B. J. Heij, A. A. Balkema, Publishers/Swets \& Zeitlinger Publishers, Lisse, The Netherlands, 2001.

Rasch, P. J., Mahowald, N. M. and Eaton, B. E.: Representations of transport, convection and the hydrologic cycle in chemical transport models: Implications for the modeling of short lived and soluble species. J. Geophys. Res., 102, 28 127-28 138, 1997.

Richter, A., Eyring, V., Burrows, J. P., Bovensmann, H., Lauer, A., Sierk, B., and Crutzen, P. J.: Satellite measurements of $\mathrm{NO}_{2}$ from international shipping emissions, Geophys. Res. Lett., 31, L23110, doi:10.1029/2004GL020822, 2004.

Sadourny, R. and Laval, K.: January and July performance of the LMD general circulation model, in: New Perspectives in Climate Modeling, edited by: A. Berger and C. Nicolis, pp.173-197, Elsevier, 1984.

Sausen, R., Isaksen, I. S. A., Grewe, V., Hauglustaine, D. A., Lee, D. S., Myhre, G., Köhler, M. O., Pitari, G., Schumann, U., Stordal, F., and Zerefos, C.: Aviation radiative forcing in 2000: An update on IPCC (1999), Meteorol. Z., 14, 555-561, 2005.

Schreier, M., Kokhanovsky, A. A., Eyring, V., Bugliaro, L., Mannstein, H., Mayer, B., Bovensmann, H., and Burrows, J. P.: Impact of ship emissions on the microphysical, optical and radiative properties of marine stratus: a case study, Atmos. Chem. Phys., 6, 4925-4942, 2006, http://www.atmos-chem-phys.net/6/4925/2006/.

Scorer, R. S.: Ship trails, Atmos. Environ., 21, 1417-1425, 1987.

Shindell, D. T., Faluvegi, G., Stevenson, D. S., Emmons, L. K., Lamarque, J.-F., Pétron, G., Dentener, F. J., Ellingsen, K., Amann, M., Atherton, C. S., Bergmann, D. J., Bey, I., Butler, T., Cofala, J., Collins, W. J., Derwent, R. G., Doherty, R. M., Drevet, J., Eskes, H. J., Fiore, A. M., Gauss, M., Hauglustaine, D. A., Horowitz, L. W., Isaksen, I. S. A., Krol, M. C., Lawrence, M. G., Montanaro, V., Müller, J.-F., Pitari, G., Prather, M. J., Pyle, J. A., Rast, S., Rodriguez, J. M., Sanderson, M. G., Savage, N. H., Schultz, M. G., Strahan, S. E., Sudo, K., Szopa, S., Unger, N., van Noije, T. P. C., Wild, O., and Zeng, G.: Multimodel simulations of carbon monoxide: Comparison with observations and projected near-future changes, J. Geophys. Res., 11, D19306, doi:10.1029/2006JD007100, 2006.

Simmonds, P. G., Manning, A. J., Derwent, R. G., Ciais, P., Ramonet, M., Kazan, V., and Ryall, D.: A burning question. Can recent growth rate anomalies in the greenhouse gases be attributed to large-scale biomass burning events? Atmos. Environ., 39(14), 2513-2517, 2005.

Singh, H. B., Brune, W. H., Crawford, J. H., Jacob, D. J., and Russell, P. B.: Overview of the Summer 2004 Intercontinental Chemical Transport Experiment-North America (INTEX-A), J. Geophys. Res., 111, D24S01, doi:10.1029/2006JD007905, 2006.

Song, C. H., Chen, G., Hanna, S. R., Crawford, J., and Davis, D. D.: Dispersion and chemical evolution of ship plumes in the marine boundary layer: Investigation of $\mathrm{O}_{3} / \mathrm{NO}_{\mathrm{y}} / \mathrm{HO}_{\mathrm{x}}$ chemistry version, J. Geophys. Res., 108, 4143, doi:10.1029/2002JD002216, 
2003.

Stevenson, D. S., Johnson, C. E., Collins, W. J., Derwent, R. G., Shine, K. P., and Edwards, J. M.: Evolution of tropospheric ozone radiative forcing, Geophys. Res. Lett. 25, 3819-3822, 1998.

Stevenson, D. S., Doherty, R. M., Sanderson, M. G., Collins, W. J., Johnson, C. E., and Derwent, R. G.: Radiative forcing from aircraft $\mathrm{NO}_{\mathrm{x}}$ emissions: mechanisms and seasonal dependence, $\mathrm{J}$. Geophys. Res., 109, D17307, doi:10.1029/2004JD004759, 2004.

Stevenson, D. S., Dentener, F. J., Schultz, M. G., Ellingsen, K., van Noije, T. P. C., Wild, O., Zeng, G., Amann, M., Atherton, C. S., Bell, N., Bergmann, D. J., Bey, I., Butler, T., Cofala, J., Collins, W. J., Derwent, R. G., Doherty, R. M., Drevet, J., Eskes, H. J., Fiore, A. M., Gauss, M., Hauglustaine, D. A., Horowitz, L. W., Isaksen, I. S. A., Krol, M. C., Lamarque, J.-F., Lawrence, M. G., Montanaro, V., Müller, J.-F., Pitari, G., Prather, M. J., Pyle, J. A., Rast, S., Rodriguez, J. M., Sanderson, M. G., Savage, N. H., Shindell, D. T., Strahan, S. E., Sudo, K., and Szopa, S.: Multimodel ensemble simulations of present-day and near-future tropospheric ozone, J. Geophys. Res., 111, D08301, doi:10.1029/2005JD006338, 2006.

Sudo, K., Takahashi, M., Kurokawa, J., and Akimoto, H.: CHASER: A global chemical model of the troposphere 1. Model description, J. Geophys. Res., 107 (D17), 4339, doi:10.1029/2001JD001113, 2002a.

Sudo, K., Takahashi, M., and Akimoto, H.: CHASER: A global chemical model of the troposphere 2. Model results and evaluation, J. Geophys. Res., 107 (D21), 4586, doi:10.1029/2001JD001114, 2002b.

Sudo, K., Takahashi, M., and Akimoto, H.: Future changes in stratosphere-troposphere exchange and their impacts on future tropospheric ozone simulations, Geophys. Res. Letters, 30, 2256 10.1029/2003GL018526, 2003.

Sundet, J. K.: Model Studies with a 3-D Global CTM using ECMWF data. Ph.D. thesis., Dept. of Geophysics, University of Oslo, Norway, 1997.

Times Books: The Times Atlas of the World Comprehensive Edition $9^{\text {th }}$ edn, London, 1992.

van der Werf, G. R., Randerson, J. T., Collatz, G. J., Giglio, L., Kasibhatla, P. S., Arellano Jr., A. F., Olsen, S. C., and Kasischke, E. S.: Continental-scale partitioning of fire emissions during the 1997 to $2001 \mathrm{El}$ Niño/La Niña period, Science, 303, 7376, 2004. van Noije, T. P. C., Eskes, H. J., van Weele, M., and van Velthoven, P. F. J.: Implications of the enhanced Brewer-Dobson circulation in European Centre for Medium-Range Weather Forecasts reanalysis ERA-40 for the stratosphere-troposphere exchange of ozone in global chemistry-transport models, J. Geophys. Res., 109, D19308, doi:10.1029/2004JD004586, 2004.

van Noije, T. P. C., Eskes, H. J., Dentener, F. J., Stevenson, D. S., Ellingsen, K., Schultz, M. G., Wild, O., Amann, M., Atherton, C. S., Bergmann, D. J., Bey, I., Boersma, K. F., Butler, T., Cofala, J., Drevet, J., Fiore, A. M., Gauss, M., Hauglustaine, D. A., Horowitz, L. W., Isaksen, I.S.A., Krol, M. C., Lamarque, J.-F., Lawrence, M. G., Martin, R. V., Montanaro, V., Müller, J.-F., Pitari, G., Prather, M. J., Pyle, J. A., Richter, A., Rodriguez, J. M., Savage, N. H., Strahan, S. E., Sudo, K., Szopa, S., and van Roozendael, M.: Multi-model ensemble simulations of tropospheric $\mathrm{NO}_{2}$ compared with GOME retrievals for the year 2000, Atmos. Chem. Phys., 6, 2943-2979, 2006, http://www.atmos-chem-phys.net/6/2943/2006/.

von Glasow, R., Lawrence, M. G., Sander, R., and Crutzen, P. J.: Modeling the chemical effects of ship exhaust in the cloud-free marine boundary layer, Atmos. Chem. Phys., 3, 233-250, 2003, http://www.atmos-chem-phys.net/3/233/2003/.

von Kuhlmann, R., Lawrence, M. G., Crutzen, P. J., and Rasch, P. J.: A model for studies of tropospheric ozone and non-methane hydrocarbons: Model description and ozone results, J. Geophys. Res., 108(D9), 4294, doi:10.1029/2002JD002893, $2003 \mathrm{a}$.

von Kuhlmann, R., Lawrence, M. G., Crutzen, P. J., and Rasch, P. J.: A model for studies of tropospheric ozone and non-methane hydrocarbons: Model evaluation of ozone-related species, J. Geophys. Res., 108(D23), 4729, doi:10.1029/2002JD003348, $2003 \mathrm{~b}$.

Wild, O. and Prather, M. J.: Excitation of the primary tropospheric chemical mode in a global 3-D model, J. Geophys. Res., 105, 24 647-24 660, 2000.

Wild, O. and Prather, M. J.: Global tropospheric ozone modeling: Quantifying errors due to grid resolution, J. Geophys. Res., 111, D11305, doi:10.1029/2005JD006605, 2006.

Wild, O., Sundet, J. K., Prather, M. J., Isaksen, I. S. A., Akimoto, H., Browell, E. V., and Oltmans, S. J.: CTM Ozone Simulations for Spring 2001 over the Western Pacific: Comparisons with TRACE-P Lidar, ozonesondes and TOMS columns, J. Geophys. Res., 108 (D21), 8826, doi:10.1029/2002JD003283, 2003. 